\title{
Biological synthesis of metallic nanoparticles: plants, animals and microbial aspects
}

\author{
Ratul Kumar Das ${ }^{1,2} \cdot$ Vinayak Laxman Pachapur' ${ }^{1}$ Linson Lonappan ${ }^{1} \cdot$ \\ Mitra Naghdi $^{1}$ - Rama Pulicharla ${ }^{1}$-Sampa Maiti ${ }^{1}$ Maximiliano Cledon ${ }^{1,3}$. \\ Larios Martinez Araceli Dalila ${ }^{1} \cdot$ Saurabh Jyoti Sarma ${ }^{4} \cdot$ Satinder Kaur Brar $^{1}$
}

Received: 12 July 2017 / Accepted: 14 September 2017/Published online: 9 October 2017

(c) Springer International Publishing AG 2017

\begin{abstract}
The green synthesis (GS) of different metallic nanoparticles (MNPs) has re-evaluated plants, animals and microorganisms for their natural potential to reduce metallic ions into neutral atoms at no expense of toxic and hazardous chemicals. Contrary to chemically synthesized MNPs, GS offers advantages of enhanced biocompatibility and thus has better scope for biomedical applications. Plant, animals and microorganisms belonging to lower and higher taxonomic groups have been experimented for GS of MNPs, such as gold (Au), silver (Ag), copper oxide $(\mathrm{CuO})$, zinc oxide $(\mathrm{ZnO})$, iron $\left(\mathrm{Fe}_{2} \mathrm{O}_{3}\right)$, palladium $(\mathrm{Pd})$, platinum $(\mathrm{Pt})$, nickel oxide $(\mathrm{NiO})$ and magnesium oxide $(\mathrm{MgO})$. Among the different plant groups used for GS, angiosperms and algae have been explored the most with great success. GS with animal-derived biomaterials, such as chitin, silk (sericin, fibroin and spider silk) or cell extract of invertebrates have also been reported. Gram positive and gram negative bacteria, different fungal species and virus particles have also shown their abilities in the reduction of metal ions. However, not a thumb rule, most of the
\end{abstract}

Satinder Kaur Brar

satinder.brar@ete.inrs.ca

1 INRS-ETE, Université du Québec, 490, Rue de la Couronne, Quebec City, QC G1K 9A9, Canada

2 Teri-Deakin Nano Biotechnology Centre, The Energy and Resources Institute, Gual Pahari, Gurgaon, Haryana 122 001, India

3 Centro de Investigación Aplicada y Transferencia Tecnológica en Recursos Marinos Almirante Storni (CIMAS), Universidad nacional del Comahue- Prov de Rio Negro- CONICET, Guemes 1030, (8520), San Antonio Oeste, Río Negro, Argentina

4 Department of Civil Engineering, The University of Calgary, 2500 University Dr NW, Calgary, AB T2N 1N4, Canada reducing agents sourced from living world also act as capping agents and render MNPs less toxic or more biocompatible. The most unexplored area so far in GS is the mechanism studies for different natural reducing agents expect for few of them, such as tea and neem plants. This review encompasses the recent advances in the GS of MNPs using plants, animals and microorganisms and analyzes the key points and further discusses the pros and cons of GS in respect of chemical synthesis.

Keywords Metallic nanoparticles · Green synthesis · Plant $\cdot$ Microorganism and animal

\section{Introduction}

The conceptual beginning of 'green chemistry' (GC) and 'nanotechnology' (NT) is among the great scientific events that influenced intellectual input in designing experiments with a goal of environmental safety and size reduction. Although GC and NT were designed with their own doctrines, interception of these two domains paved way to a new green and nanoscale-oriented science termed as 'green nanotechnology' (GN). In this regard, the great contribution of Paul T. Anastas and Richard Phillips Feynman toward making NT and GC feasible is sincerely appreciated [1-4]. The twelve green commands, well known as 'green chemistry principles' (GCP) followed in GN, strongly suggest searching for green options for a nano-product. However, this concept may suffer from unfeasibility constraints as green option may not be available for each nano-designed formulation. While pursuing the technical advantages of nano-dimension over bulk, one should be aware of the negative impacts of nano-sized materials. This issue has been well addressed by experts, and they have expressed their 
opinion toward possible solution [5-17]. Interestingly, nature responded to this issue in an unforeseen fashion. Recalling the findings of Lovely et al. on iron nanoparticles (magnetite) synthesis by bacteria, the exploration of nature's ability to reduce metal cations to zero valent state has been expanded at a greater pace [18]. Last three decades have witnessed the advancement of this green science, and NT has been enriched with nature directed biosynthesis of nanoentities. To distinguish this green approach of nano-synthesis from the conventional chemical or physical methods, the term 'green synthesis' (GS) has been coined for this new scientific discipline. Apart from ethnobotanical and medicinal chemistry prospective, GS may be considered as another ground for reaching natural repository of green elements in the form of phytochemicals, animal-derived biomaterials and biomolecules of microbial origin. Researchers have expedited the search for new molecules that can reduce metallic ions into zero valent atoms and then support bottomup approach of MNPs synthesis. GS is also believed to be responsible for binding biomolecules to the surfaces of the MNPs during their synthesis. This phenomenon is commonly known as 'capping' in GS field. From comparative stand point of view, plants have been the prime target for GS and the success rate is also very high as compared to animal and microbial-mediated GS. Extensive research with plants belonging to different taxonomic groups has revealed the capability of GS and capping behavior [19-26]. Apart from the plant kingdom, different animal-derived biomolecules, such as alginate, chitosan and silk, have exhibited potential for application in GS [27-31]. Recently, invertebrate species have been experimented for their ability to synthesize MNPs [32]. In the microbial world, bacteria, fungi and viruses have responded positively toward the MNPs synthesis via GS [33-38]. The progress made in this direction has been well analyzed and discussed by different experts [39-43]. It is obvious that GS has opened a new avenue for NT and GC for conceptualizing new ideas for the implementation in applied nanotechnology. However, GS is still in its infancy and needs more research input to announce it as an independent and well-authenticated discipline for global acceptance. This review covers important findings of GS on different MNPs synthesis by plants, animal-derived biomaterials and microbial biomolecules, followed by an in-depth analysis on the pros and cons of GS and future perspectives.

\section{Plant-mediated synthesis of metallic nanoparticles}

This section encompasses the progress made in the plantmediated GS covering all taxonomic groups used so far (Fig. 1). As the number of plants being explored for GS is exceedingly high, inclusion of all of them is not intended in some subsections. Plants with medicinal or clinical importance that have been explored for GS have been given priority over randomly selected ones. Mechanism of MNPs synthesis by GS has been comprehended to know the ability of plants to reduce metallic ions and justify their capping nature.

\section{Angiosperms}

Being at the top of plant evolutionary lineage, angiosperms are being advantageously exploited for GS of MNPs. Worldwide distribution, easy access and socioeconomic culture have brought people closer to this taxonomic group of plants. Angiosperm has always played a vital role in the natural remedies of human and other animal diseases [44]. Moreover, edible nature of many angiosperm species makes it more attractive in pursuing their scientific importance. In terms of GS, the details on the first report of application of angiosperms for GS are either not well documented or disputed. If we look at the global scenario of GS research, the cosmopolitan nature of angiosperms has helped in executing the nature's reducing ability toward the rapid advancement of this green domain of science. Being highly rich in plant bioresources, Asian countries have significantly contributed toward enriching the GS library with new findings. However, not all randomly selected plant species can be justified for being put to use into the GS practices. This has been one of the prime drawbacks of GS methodology and can be attributed to the lack of authentic guidelines with global acceptance. Pertaining to this fact, exploration for new plant species has been unexpectedly expedited in the recent times. Undoubtedly, such efforts have enriched the GS repository and encouraged research progress in this direction. The major issue is to emphasize the revelation of GS mechanism behind each plant species used and validate its selection over others. It is almost impossible to track down all angiospermic plants explored for GS and update them accordingly. An attempt has been made to generate a summarized view of the representative angiospermic plant species explored for GS as shown in Table 1.

The representative examples included in Table 1 show the variation in MNPs type (of different metals) achieved using GS methodology. This is an indication of high reducing potentials of plant phytochemicals that neutralize uni- or multivalent metallic cations $\left(\mathrm{M}^{\mathrm{n}+}\right)$ into neutral atoms $\left(\mathrm{M}^{\mathrm{o}}\right)$ for MNPs synthesis. Metallic cations with larger (e.g., $\left.\mathrm{Au}^{3+}+3 \mathrm{e}^{-} \rightarrow \mathrm{Au}^{\circ}(s), E^{o}(\mathrm{~V})=1.52\right)$ and smaller standard reduction potentials $\left(\mathrm{Mg}^{2+}+2 \mathrm{e}^{-} \rightarrow-\right.$ $\left.\operatorname{Mg}(s), E^{o}(\mathrm{~V})=-2.372\right)$ are reduced by the plant molecules with lower ionization potentials. Most of the studies with angiospermic species were focused on the GS of $\mathrm{Au}$ or Ag nanoparticles, and reports on other MNPs are scanty. 
Fig. 1 Schematic depiction of plant taxonomic groups used for green synthesis of different metallic nanoparticles and summary of their present status in application

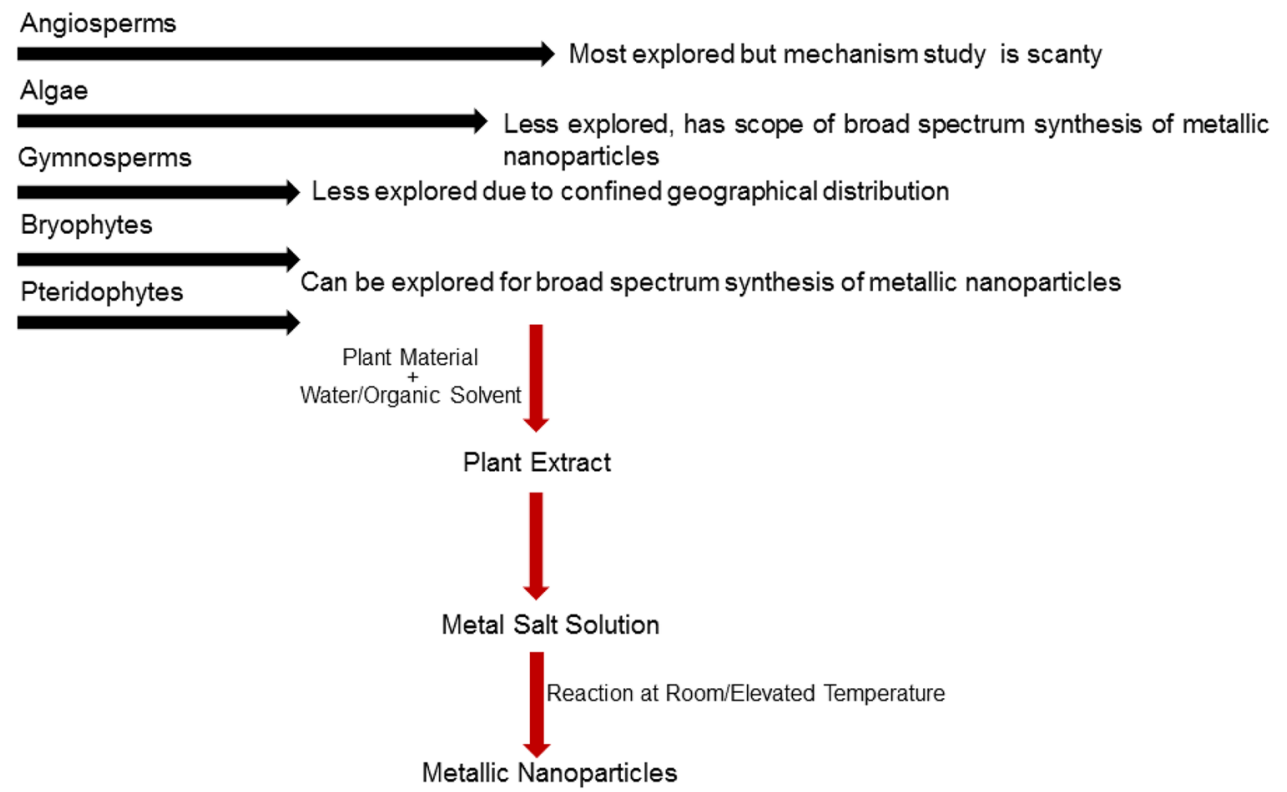

This might be due to the failure of the plant molecules to reduce metal cations with lower reduction potentials. Screening of plant molecules with higher electron donating capacity can be a good option for making GS a common modality of MNPs synthesis. It is obvious that innumerable angiospermic plant species are being used as a part of our diet or remedies for diseases. Thus, apart from the reducing nature of selected plant species, some other important technical aspects, such as edibility, socioeconomic importance, ethnobotanical background and availability, should be considered during plant selection. Randomized selection procedure might result in MNPs synthesis, but biocompatibility issue may put it in a non-progressive research interest. Angiospermic plant species, such as Azadirachta indica, Camellia sinensis, Aloe vera and Centella asiatica, are the frontline examples of plant species that have been highly explored for their medicinal values and also have clinical relevancy (Table 1). Capping behavior of the phytochemical molecules makes MNPs biocompatible as confirmed from cytotoxicity assay [66, 67]. However, size and shape of the MNPs play decisive role in the determination of overall biocompatibility [68-73]. It is highly desired that green synthesized MNPs have a size range less than $100 \mathrm{~nm}$ for their biomedical applications. As seen in Table 1, MNPs may have a size range of 2-500 nm, which is of highly variable nature. Controlling the size and shape of MNPs can now be declared as the most challenging task for the researchers working in GS field. Contemporary findings suggest a relationship between the applied parameters (such as plant extract concentrations, metallic ion concentrations and reaction time and temperature) and morphology (shape and size) of the obtained MNPs $[74,75]$. Although this claim might be true for some instances, we are yet to have a consensual view on this issue. Moreover, atom economy is another underexplored area in GS that needs attention from the experts. The reaction conditions applied for GS exhibit variations and seem to be not guided by any authentic guidelines. Reaction temperature as low as $25^{\circ} \mathrm{C}$ (room temperature) to higher temperature, such as $80-150{ }^{\circ} \mathrm{C}$, has been tested for GS of different MNPs (Table 1). From chemistry point of view, it is obvious that reaction kinetics is influenced by reaction temperature and thus determines the reaction completion time. GS studies on variation of reaction temperature mostly resulted in changed morphology of the synthesized MNPs, and reasons are well explained [76-78]. Photosynthesis of Pd nanoparticles with Asparagus racemosus using sunlight is a remarkable effort in making GS cost-effective [65]. More experimentation with other angiospermic species can make this approach a common modality for GS reaction without artificial energy input. However, MNPs synthesis at room temperature is more desired to make GS free of heat application and thus more cost-effective. If GS is proposed for scale-up studies, this issue is of great concern. Moreover, making GS methodology free of use of toxic and hazardous organic solvents for plant extract preparation is also important from environmental perspectives. From the list of representative examples of Table 1, it is obvious that common choice of solvent has been water with few exceptions, a good indication for retaining the core meaning of GS. Being considered as a benign solvent, water has the scope of being used in GS at large scale.

Probably, the least explored area in GS research is the uncovering of underlying mechanisms of MNPs synthesis by the plant extracts. As compared to the number of reports 
Table 1 Representative examples of angiosperm plant species used for green synthesis of different metallic nanoparticles

\begin{tabular}{|c|c|c|c|c|c|c|}
\hline Plant species & $\begin{array}{l}\text { Plant material and } \\
\text { solvent }\end{array}$ & $\begin{array}{l}\text { Reaction } \\
\text { temperature }\end{array}$ & $\begin{array}{l}\text { Type of } \\
\text { MNPs }\end{array}$ & Mechanism/causative agent & $\begin{array}{l}\text { Size } \\
(\mathrm{nm})\end{array}$ & References \\
\hline Azadirachta indica & Kernel, water & Room temperature & $\mathrm{Au}, \mathrm{Ag}$ & Azadirachtin & $50-100$ & {$[45]$} \\
\hline Camellia sinensis & Leaves, water & Room temperature & $\mathrm{Au}$ & $\begin{array}{l}\text { Catechins, theaflavins and } \\
\text { thearubigins }\end{array}$ & $15-42$ & [46] \\
\hline Jatropha curcas $L$. & Latex, water & Room temperature & $\mathrm{Pb}$ & Curcacycline A and Curcacycline B & $10-12.5$ & {$[21]$} \\
\hline $\begin{array}{l}\text { Geranium leaves } \\
\text { plant extract }\end{array}$ & Leaves, water & Room temperature & $\mathrm{Ag}$ & Terpenoids (not specified) & $16-40$ & [47] \\
\hline \multirow[t]{2}{*}{ Nelumbo nucifera } & Leaves, water & Room temperature & $\mathrm{Ag}$ & Not mentioned & $25-80$ & [48] \\
\hline & Leaves, water & Room temperature & & & $30-40$ & [49] \\
\hline $\begin{array}{l}\text { Lemongrass plant } \\
\text { extract }\end{array}$ & Leaves, water & Room temperature & $\mathrm{Au}$ & $\begin{array}{l}\text { Sugar derivative molecules (not } \\
\text { specified) }\end{array}$ & $200-500$ & {$[50]$} \\
\hline Avena sativa & Stems, water & Room temperature & $\mathrm{Au}$ & Not mentioned & $5-85$ & {$[51]$} \\
\hline \multirow[t]{2}{*}{ Aloe vera } & Leaves, water & Room temperature & $\mathrm{Ag}$ & Not specified & 70 & {$[52]$} \\
\hline & Leaves, water & $\begin{array}{l}\text { Room temperature } \\
\text { and } 80^{\circ} \mathrm{C}\end{array}$ & & & 15.2 & {$[53]$} \\
\hline $\begin{array}{l}\text { Cinnamomum } \\
\text { camphora }\end{array}$ & $\begin{array}{l}\text { Leaves, no solvent } \\
\text { (dried biomass) }\end{array}$ & $30^{\circ} \mathrm{C}$ & $\begin{array}{l}\mathrm{Ag} \\
\mathrm{Au}\end{array}$ & $\begin{array}{l}\text { Polyol components and heterocyclic } \\
\text { components }\end{array}$ & $\begin{array}{l}64.8 \\
15-25\end{array}$ & {$[54]$} \\
\hline Alfa sprouts & Living plant & Not applicable & $\mathrm{Ag}$ & In situ synthesis & $2-20$ & {$[55]$} \\
\hline $\begin{array}{l}\text { Syzygium } \\
\text { aromaticum }\end{array}$ & Flower buds, water & Room temperature & $\mathrm{Cu}$ & Eugenol (not specified) & $5-40$ & {$[56]$} \\
\hline Euphorbia esula L & Leaves, water & Room temperature & $\mathrm{Cu}$ & Flavonoids and phenolic acids & $20-110$ & {$[57]$} \\
\hline Camellia sinensis & Leaves, water & Room temperature & $\mathrm{Fe}_{2} \mathrm{O}_{3}$ & Polyphenols & $5-15$ & {$[58]$} \\
\hline Eucalyptus & Leaves, water & Room temperature & $\mathrm{Fe}_{2} \mathrm{O}_{3}$ & $\begin{array}{l}\text { Epicatechin and quercetin- } \\
\text { glucuronide }\end{array}$ & $20-80$ & [59] \\
\hline $\begin{array}{l}\text { aloe barbadensis } \\
\text { miller }\end{array}$ & Leaves, water & $150{ }^{\circ} \mathrm{C}$ & $\mathrm{ZnO}$ & $\begin{array}{l}\text { Phenolic compounds, terpenoids or } \\
\text { proteins (not specified) }\end{array}$ & $25-40$ & {$[60]$} \\
\hline $\begin{array}{l}\text { Nephelium } \\
\text { lappaceum L. }\end{array}$ & Peels, hydro-ethanol & $80^{\circ} \mathrm{C}$ & $\mathrm{MgO}$ & Not mentioned & 100 & {$[61]$} \\
\hline $\begin{array}{l}\text { Nephelium } \\
\quad \text { lappaceum L }\end{array}$ & Peels, hydro-ethanol & $80{ }^{\circ} \mathrm{C}$ & $\mathrm{NiO}$ & Nickel-ellagate complex formation & 50 & {$[62]$} \\
\hline Clitoria ternatea & $\begin{array}{l}\text { Whole plant, ethanol } \\
(70 \%)\end{array}$ & Room temperature & $\mathrm{MgO}$ & Bioactive compounds (not specified) & $50-400$ & {$[63]$} \\
\hline Cintella asiatica & Leaves, ethanol $(70 \%)$ & Room temperature & $\mathrm{Au}$ & Phenolic compounds (not specified) & $\begin{array}{l}9.3 \text { and } \\
11.4\end{array}$ & {$[24]$} \\
\hline Camellia sinensis & Leaves, water & Room temperature & $\mathrm{Pt}$ & Pure tea polyphenol & $30-60$ & {$[64]$} \\
\hline $\begin{array}{l}\text { Asparagus } \\
\text { racemosus }\end{array}$ & Tuber cortex, water & Sun light & $\mathrm{Pd}$ & Bioactive compounds (not specified) & $1-6$ & {$[65]$} \\
\hline
\end{tabular}

on GS with angiospermic species, mechanism study or information on causative agents for reduction and capping behavior has not been well explored. In this regard, the plant species included in Table 1 shows some of the very important examples for specific and general elaboration on mechanism/causative agents. The plant species, Camellia sinensis (tea), can be considered as one of the well-explored plants or GS mechanism study. Isolation and purification of the tea biomolecules, viz. catechins, theaflavins and thearubigins and their experimentation with $\mathrm{Au}^{3+}$ cations confirmed the involvement of these biomolecules in the GS of Au nanoparticles [46, 64]. Similarly, isolation and purification of the tetra-nortriterpenoid azadirachtin has confirmed the reducing and capping role of Azadirachta indica in the GS of $\mathrm{Au}$ and Ag nanoparticles [45]. Commercially available pure tea polyphenol (from Sigma) has been applied for the green synthesis of $\mathrm{Pt}$ nanoparticles [64]. These findings can be a very good platform in designing experiments for GS at large scale. Involvement of phenolic compounds, such as epicatechin and quercetin-glucuronide in the GS of MNPs (e.g., $\mathrm{Fe}_{2} \mathrm{O}_{3}$ ), is important as their pure formulations are also commercially available [59]. The plant species, Jatropha curcas $L$, has been claimed to reduce metal cations through 
cyclic peptide molecules, curcacycline A and curcacycline B present in its latex [21]. Structural elucidation of these peptide molecules has helped with better comprehension of the activities of these molecules $[79,80]$. Reports on in situ synthesis (live plant) of MNPs are scanty. The experiment with the plant species, Alfa sprouts, for in situ synthesis of $\mathrm{Ag}$ nanoparticles is a leading example [55]. Apart from these specific findings, researchers seem to be more inclined toward a general mechanistic approach for explaining the GS mechanism for different angiospermic plant species. The trend shows that common phytochemical constituents, such as phenols, alkaloids, terpenoids and some pigments, have been held responsible for the GS of different MNPs [24, 47, 54, 56-58, 60]. But, it is high time to verify the reduction potential of each constituent for the reduction of different metal anions. Instrumental analysis, such as Fourier transform infrared spectroscopy (FTIR) and energy-dispersive X-ray spectroscopy (EDAX), often leads to the conclusion of capping nature of the plant molecules during GS of MNPs. However, these are also not inclusive and foolproof analytical tools. Downstream processing of the green synthesized MNPs may greatly affect the FTIR and EDAX findings. Next to mechanism study, GS also suffers from the lack of cytotoxicity study in majority of the reports. GS was originally designed to synthesize more biocompatible MNPs as compared to the chemically synthesized ones. Avoiding cytotoxicity issue might result in only enriching the GS repository rather than emerging into the applied field of MNPs.

Documentation on GS with angiospermic plant species has helped in building strong evidence of nature's ability to direct the biosynthesis of MNPs without the use of toxic and hazardous chemicals, such as sodium borohydride $\left(\mathrm{NaBH}_{4}\right)$ and tri-sodium citrate $\left(\mathrm{Na}_{3} \mathrm{C}_{6} \mathrm{H}_{5} \mathrm{O}_{7}\right)$. The overall progress made in this newly emerged nano-green science is remarkable and most importantly, its non-confinement nature (specific geographical area of world) has made GS more generalized and attractive alternative to the conventional methods of GS. What is lacking in its current stage is the authentication of some guidelines on the plant selection procedure, upstream and downstream processing of MNPs, biocompatibility check of MNPs and desired characteristics for biomedical applications. Moreover, protocol designing for large-scale production of GS is another key point to be focused in future.

\section{Gymnosperms}

The evolution of the gymnosperms is a crucial step to plant reproduction; they were the first plants to have seeds. The extant gymnosperms are distributed nearly everywhere on earth. Wide diversity of plants makes each plant family unique with well organized and having different valued metabolites. These biomolecules (metabolites) are responsible for reduction of metals to form MNPs. Bio-sorption and bio-reduction of metal ions in prokaryotes have been exploited for few decades, and recent studies suggested that eukaryotes were also capable of reducing metal ions. Many studies reported the formation and bioaccumulation of MNPs in plants mediated by various reducing/stabilizing agents of cells. Having more genetic information of eukaryotes was helpful in understanding of genetic encoding of these agents and their functions. Sharma et al. [81] and Cirtiu et al. [82] showed that these reduced and stabilized MNPs in plant cells were used as catalyst in detoxifying pollutants. Copper $(\mathrm{Cu})$ is required as micronutrient for plants, and higher concentration of it is detoxified by plants by the reduction of $\mathrm{Cu}$ ions into neutral atoms and subsequently into $\mathrm{Cu}$ nanoparticles [83]. Studies on biosynthesis of MNPs using gymnosperms are limited. This is probably due to less explored and less access to this plant groups across the world. Conversely, biosynthesis of MNPs is dependent on phytochemical composition of plant cells and gymnosperms are vascular plants as angiosperms; hence, research on biosynthesis of MNPs using gymnosperms is yet to be explored. Based on the mechanism of NPs formation, it was concluded that size, morphology, quantity of NPs are principally dependent on the plant type and its parts, $\mathrm{pH}$ of synthesis and bioavailability of metals [84-88].

Most of the research on the biosynthesis of MNPs was carried out in angiosperms and principally on silver $(\mathrm{Ag})$ and gold $\mathrm{(Au}) \mathrm{NPs}$ synthesis using plant biomass, plant extract, or plants itself. The mechanism of metal reduction and stabilization by phytochemicals has also been explored in angiosperms. Due to common phytochemical families among plant groups, their structural evaluation for gymnosperms in comparison with angiosperms may be helpful in extrapolating the mechanism of MNPs formation. Table 2 shows the typical gymnospermic plants explored for biosynthesis of MNPs. Jha and Prasad [89] proved that activation of antioxidative system in Cycas plant under metallic stress $\left(\mathrm{AgNO}_{3}\right)$ led to $\mathrm{Ag}^{\circ} \mathrm{NPs}$ formation. Leaves of Cycas plant contain phenolic compounds (amentoflavone and hinokiflavone) which are characteristic biflavonyls limited to gymnospermic plants and also the carbonyl (ascorbic acid) and thiols (metallothionein) groups involved in this bioprocess. Comparing the synthesis mechanism of Ag NPs with angiosperms [90, 91], the main functional groups and the phytochemical families responsible are similar but actual chemical compounds are different. This may affect the physicochemical properties of formed MNPs. Noruzi et al. reported green synthesis of Au NPs using the reduction capability of aqueous extract of cypress (Thuja orientalis) leaves. The reaction was 
Table 2 Representative examples of gymnosperm plant species explored for green synthesis of metallic nanoparticles

\begin{tabular}{|c|c|c|c|c|c|c|}
\hline $\begin{array}{l}\text { Plant } \\
\text { species }\end{array}$ & $\begin{array}{l}\text { Plant material and } \\
\text { solvent }\end{array}$ & $\begin{array}{l}\text { Type of } \\
\text { MNPs }\end{array}$ & Reaction temperature & Size $(\mathrm{nm})$ and shape & Mechanism/causative agent & References \\
\hline $\begin{array}{l}\text { Pinus } \\
\quad \text { Eldarica }\end{array}$ & Bark, water & $\mathrm{Ag}$ & $25-150^{\circ} \mathrm{C}$ & $10-40$, spherical & Phenolic compounds & [84] \\
\hline $\begin{array}{l}\text { Pinus } \\
\text { thunbergii }\end{array}$ & Pine cone, water & $\mathrm{Ag}$ & Room temperature & $\begin{array}{l}\text { 35, triangular and } \\
\text { hexagonal }\end{array}$ & Hydroxyl and carbonyl groups & {$[85]$} \\
\hline $\begin{array}{l}\text { Pinus } \\
\quad \text { resinosa }\end{array}$ & Bark, water & $\begin{array}{l}\mathrm{Pb} \\
\mathrm{Pt}\end{array}$ & $80^{\circ} \mathrm{C}$ & $\begin{array}{l}\text { 16-20, spherical } \\
6-8, \text { irregular }\end{array}$ & Fulvic acid & {$[86]$} \\
\hline $\begin{array}{l}\text { Pinus } \\
\text { densiflora }\end{array}$ & Leaves, water & $\mathrm{Ag}$ & $25-95{ }^{\circ} \mathrm{C}$ & 15-500, cubic & Not mentioned & [87] \\
\hline Cycas & Leaf, $50 \%$ ethanol & $\mathrm{Ag}$ & Room temperature & $2-6$, spherical & $\begin{array}{l}\text { Ascorbic/ } \\
\text { dehydroascorbic acid and } \\
\text { amenti/hinoki } \\
\text { flavones }\end{array}$ & [89] \\
\hline $\begin{array}{l}\text { Ginkgo } \\
\text { biloba }\end{array}$ & Leaves, water & $\mathrm{Ag}$ & $\begin{array}{c}25-95^{\circ} \mathrm{C} \text { room } \\
\text { temperature }\end{array}$ & $\begin{array}{l}15-50 \\
\text { cubic }\end{array}$ & Proteins and metabolites & {$[87,88]$} \\
\hline & & $\mathrm{Au}$ & & $5-40$, spherical & & \\
\hline
\end{tabular}

completed in $10 \mathrm{~min}$ at room temperature with more than $90 \%$ reaction progress. The synthesized Au NPs were mostly spherical, and their average particle size depended strongly on $\mathrm{pH}$ and concentration of extract and ranged from 5 to $94 \mathrm{~nm}$. Their X-ray and FTIR study confirmed the crystalline structure and binding of capping molecules to the surface of particles, respectively [92]. In a similar study, Nasrollahzadeh and Sajadi synthesized $\mathrm{Cu}$ NPs with the size of 15-20 nm using Ginkgo biloba Linn leaves extract as a reducing and stabilizing agent at room temperature. Since no toxic reagents were used in this synthesis method, it can be considered as an environmental friendly process [93]. Kalpana et al. used Torreya nucifera leaves extract for synthesis of Ag NPs. They found that temperature and concentration of extract had key roles in determining size and shape of NPs, respectively. Generally, the synthesized NPs were spherical with the size ranging between 10 and $125 \mathrm{~nm}$ [94]. In a related study, Johnson and Prabu observed a rapid reduction capability of Cycas circinalis leaves extracts for $\mathrm{Ag}$ ions which led to the formation of crystalline Ag NPs. Similarly, synthesized NPs had spherical shape with diameter of 13-51 nm [95].

High content of phenolic compounds was reported in pine family of gymnospermic plant leaves and bark. Velmurugan et al. [85] stated that hydroxyl and carboxyl groups of phenolic compounds were involved in MNPs synthesis in Pinus thunbergii. Mechanism and compounds used in the bioprocess were not evaluated, specifically in pine plants. Effect of process parameters such as temperature and $\mathrm{pH}$ on NPs size, shape and efficiency was valued in these plants. Studied proved that high temperature, $\mathrm{pH}$ and duration have positive control on NPs properties.
According to the reports, formation of $\mathrm{Au}(+1.83)$ NPs is fast as it has higher reduction potential compared to $\mathrm{Ag}$ $(+0.79)$; hence, metallic properties also affect the process parameters. FTIR results of Arundoss et al. [88] evidenced metabolites having polyphenolic functional groups and proteins responsible for the metal reduction and as surface coating molecules to stabilize the MNPs, respectively. Hence, these biological molecules of gymnospermic plant extract play an important role in formation and stabilization of MNPs which is eco-friendly and efficient alternative to conventional methods.

\section{Pteridophytes}

Traditionally, plant extracts of pteridophytes are used as antibacterial agents. The evolutionary success of pteridophytes for more than 350 million years may be due to this antibacterial activity. Studies of De Britto et al. [96] used three different pteridophyte plants of pteris genus to synthesize Ag NPs. Among the resulting NPs, plant $P$. biaurita Ag NPs have shown highest antibacterial activity. Mechanism of biosynthesis and difference in the antibacterial activity of different plant-derived NPs is yet to be studied. Table 3 presents the plants of pteridophytes used in biosynthesis process of MNPs production.

NPs derived from fern, Nephrolepis exaltata, have shown antibacterial activity against many bacterial pathogens [98]. The presence of phytochemicals, such as tannins, flavonoids, alkaloids and terpenoids in Adiantum philippense. $L$ which is similar to angiosperms, makes the plant extracts highly oxidant and might be involved in 
Table 3 Representative examples of pteridophyte plant species used for green synthesis of metallic nanoparticles

\begin{tabular}{|c|c|c|c|c|c|}
\hline Plant species & $\begin{array}{l}\text { Plant material and } \\
\text { solvent }\end{array}$ & $\begin{array}{l}\text { Type of } \\
\text { MNPs }\end{array}$ & $\begin{array}{l}\text { Reaction } \\
\text { temperature }\end{array}$ & $\begin{array}{l}\text { Size }(\mathrm{nm}) \text { and } \\
\text { shape }\end{array}$ & References \\
\hline Adiantum philippense L. (Adiantaceae) & Leaf, water & $\mathrm{Au}$ and $\mathrm{Ag}$ & $30^{\circ} \mathrm{C}$ & $10-18$ & [97] \\
\hline Nephrolepis exaltata & leaflet extract, water & $\mathrm{Ag}$ & Room temperature & 10-47, spherical & [98] \\
\hline $\begin{array}{l}\text { Pteris argyreae, Pteris confusa and Pteris } \\
\text { biaurita }\end{array}$ & Leaf, water & $\mathrm{Ag}$ & Room temperature & Not mentioned & {$[88]$} \\
\hline Adiantum capillus-verenis & Whole plant, water & $\mathrm{Ag}$ & Room temperature & 25-37, spherical & [99] \\
\hline Adiantum caudatum & Leaves, water & $\mathrm{Ag}$ & Room temperature & Not mentioned & [96] \\
\hline
\end{tabular}

producing gold and silver nanoparticles [97]. So far, studies have shown that MNPs derived from pteridophytes have enhanced antibacterial activity; this may be due to the different natural medicinal values (antioxidant and antibacterial) of the plants themselves. Still the mechanism and the comparison of antibacterial activity of derived NPs need to be compared with other plant-derived NPs. Kunjiappan et al. showed that the flavonoids present in Azolla microphylla can serve as both reducing agent and stabilizers for production of $\mathrm{Au}$ NPs at low temperature $\left(\approx 35^{\circ} \mathrm{C}\right)$. Also they claimed that the flavonoids caused Au NPs to have hepatoprotective and antioxidant effects. Their NPs had different shapes such as spherical, triangular, hexagonal and rod shape, and their size ranged from 3 to $20 \mathrm{~nm}$ with average of $8.3 \mathrm{~nm}$ [100]. In a related study, Singh reported the synthesis of Au NPs using aqueous extract of Azolla pinnata as a reducer and stabilizer at $50{ }^{\circ} \mathrm{C}$. The fabricated NPs were rod shape with the size of about $200 \mathrm{~nm}$ and also spherical with the size of about $20 \mathrm{~nm}$ [101]. In a similar investigation, Korbekandi et al. used Azolla pinnata whole plant for synthesis of polydispersed spherical Ag NPs with the mean size of $6.5 \mathrm{~nm}$ in 5 -h reaction time. They found that the optimum precursor and extract concentration for reaction were $1 \mathrm{mM}$ and dried extract equivalent to $100 \mathrm{~g}$ plant powder, respectively [102].

\section{Bryophytes}

Bryophytes are the most primitive extant terrestrial plants which lack vascular system and occupy the second largest group of land plants across the world. Bryophytes are essential in understanding the plant origin and following the plant transition to land. Similar to pteridophytes, bryophytes are not damaged by other living organisms as they produce biologically active compounds to protect themselves. Phytochemical work in bryophytes leads to usage of these biologically active substances in several ways [103]. Table 4 exemplifies the bryophytes used in the biosynthesis of MNPs. Studies showed that simple organization of plant body (thallus) of bryophytes makes the process facile. Bryophytes are the less explored plants in GS of MNPs. Acharya and Sarkar synthesized Au NPs using the of extract bryophyte gametophyte at $37^{\circ} \mathrm{C}$. The Au NPs were in spherical, triangular and hexagonal shapes with the size in the range of $42-145 \mathrm{~nm}$ [104].

\section{Algae}

Eco-friendly reducing agent, particle-stabilizing capping agent and environmentally acceptable solvent system are the three principle criteria for totally green metallic nanoparticle synthesis [108]. Algae-mediated biological synthesis of metal nanoparticles is one of them. Algae are eukaryotic aquatic oxygenic photoautotrophs [109]. Bioreduction of algae showed large potential in the development of clean green synthesis of different metallic and metal oxide nanoparticles, such as gold, silver, platinum, palladium, copper oxide, zinc oxide, cadmium sulfate, among others [110-114]. Although quite a number of algae have been found capable of synthesizing different NPs, control of the size and shape of the products, and the identification of the principals involved, understanding is still incomplete [108].Therefore, many researchers became interested in exploring the biological synthesis of algaemediated nanoparticles. Through evolution, algae have developed the capability of producing complex inorganic intracellular or extracellular structures [108]. The exact process of intracellular formation of gold nanoparticles by algal biomass is not yet fully understood [108]. The metal ions are initially trapped on the plant cell surface via electrostatic interaction between the ions and negatively charged carboxylate groups present on the cell surface. Later, the ions are reduced by cellular enzymes, leading to the formation of nuclei, which subsequently grow with further reduction of metal ions [37, 115]. In contrast, there is uptake of high amounts of Au (III) ions by Sesbania drummondii, with subsequent reduction of $\mathrm{Au}$ (III) ions to 
Table 4 Representative examples of bryophyte plant species used for green synthesis of metallic nanoparticles

\begin{tabular}{llllll}
\hline Plant species & Plant material and solvent & Type of MNPs & Reaction temperature & Size (nm) and shape & References \\
\hline Fissidens minutus & Thallus, 70\% ethanol & $\mathrm{Ag}$ & Room temperature & Not mentioned & [105] \\
Riccia liverworts & Mature thalli, water & $\mathrm{Ag}$ & Room temperature & 20-50, cuboidal and triangular & [106] \\
Anthoceros & Thallus, 70\% alcohol & $\mathrm{Ag}$ & Room temperature & 20-50, cuboidal and triangular & [107] \\
\hline
\end{tabular}

$\mathrm{Au}$ (0) inside cells [81]. In algae, both processes occur simultaneously, as gold nanoparticles are either intracellular (e.g., in the case of Rhizoclonium fontinale) or extracellular in the medium, as in Lyngbya majuscula and Spirulina subsalsa [116].

Of the various metal nanoparticles, gold and silver nanoparticles and nano-plates are of particular interest in technological applications, such as cancer hyperthermia, antimicrobial, among others [108]. Generally, single-celled green algae was found to have strong binding ability toward tetra-chloro-aurate ions/silver nitrate, to form algalbound gold/silver, which was subsequently reduced to $\mathrm{Au}$ (0)/Ag (0). The dried alga, Chlorella vulgaris, reduced approximately $88 \%$ of gold in metallic state, and the crystals of gold were accumulated in both inner and outer parts of cell surfaces with tetrahedral, decahedral and icosahedral structures [117]. Spirulina platensis is an edible blue-green alga, and the dried alga was used for the extracellular synthesis of gold, silver and $\mathrm{Au} / \mathrm{Ag}$ bimetallic nanoparticles [118]. Recently, the intracellular production of gold nanoparticles using Tetraselmis kochinensis has been reported by Senapati et al. [119]. Moreover, extracellular bio-reduction of $\mathrm{Au}$ (III)-Au (0) using biomass of the brown alga, Fucus vesiculosus, has also been reported [120]. Cyanobacteria were well known for intracellular metallic nanoparticle synthesis. Mubarak-Ali et al. has shown that protein molecule, NTDM01, present inside the cell of cyanobacteria, Oscillatoria willei, helped in reducing silver ion to metallic silver which was released outside the dead cell [121]. Moreover, different functional groups, such as hydroxyl $(-\mathrm{OH})$ from polysaccharides and different amino acids (such as tyrosine) and carboxyl anions ($\mathrm{COOH}-$ ) from various amino acids such as aspartic acid (Asp) have been identified as the most active functional groups for $\mathrm{Ag}$ ion reduction and for directing the anisotropic growth of Ag nano-plates [122]. Roni et al. used aqueous leaf extract of the seaweed Hypnea musciformis as reducer and stabilizer in a single-step synthesis of Ag NPs. The synthesized Ag NPs were mostly spherical in shape with the size range of 40-65 $\mathrm{nm}$ [123].

Several nanoparticles which have been widely explored for angiosperms, such as $\mathrm{Fe}_{2} \mathrm{O}_{3}, \mathrm{MgO}, \mathrm{NiO}$, among others, and microorganisms, such as $\mathrm{PbS}, \mathrm{ZnS}, \mathrm{CdS}$, among others, have not been well explored for algae [108]. However, a brief summary of different metallic nanoparticles synthesized from algae is listed in Table 5.

\section{Microbial synthesis of metallic nanoparticles}

In recent years, physical and chemical techniques have been used to produce nanoparticles [37, 40]. These techniques are costly and utilize toxic chemicals during the synthesis of nanoparticles under ultraviolet irradiation, laser ablation and aerosol spray [36, 40]. While these methods are extensively used, but use of toxic chemicals is subject of concern. To overcome this problem, microbial synthesis of nanoparticles is being explored [36]. Physical approach of nanoparticle production limits lower synthesis requires higher utilization of energy, and expenses are very high. However, chemical approaches are low cost but require use of toxic solvents and trail of chemical contamination with generation of toxic by-products. Therefore, biological approach of including bacteria, fungi, yeast and viruses delivers high-yield, low cost and environmental friendly synthesis of nanoparticles [37, 40].

Microbial synthesis of nanoparticles will be a green chemistry approach and is considered an exciting area of research for future application [36, 37, 138]. Microbial synthesis with rich biodiversity of microbes, using simple microbial cultivation, under cellular, biochemical and molecular mechanisms, the rate of synthesis and improvement in nanoparticle properties of can be achieved [36]. Microbial and metal interaction is well recognized in biotechnological processes, such as bioleaching, biomineralization, biocorrosion and bioremediation $[36,139]$. The properties of nanostructured mineral crystals and metallic nanoparticles produced by microbes are similar to chemically synthesized nano-materials [139]. Many unicellular and multicellular organisms, such as bacteria (prokaryotes), fungi (eukaryotes) and viruses, produce either intracellular or extracellular inorganic materials [37, 40]. The formation of these inorganic materials to an extent can be manipulated for the shape and size by controlling the culture parameters [138].

The mechanism of intracellular and extracellular production of nano-materials is different across varied microbes [35, 37]. The intracellular mechanisms involve 
Table 5 Representative examples of algae species of used for green synthesis of metallic nanoparticles

\begin{tabular}{|c|c|c|c|c|c|c|c|}
\hline Algae species & Part used & $\begin{array}{l}\text { Solvent } \\
\text { used }\end{array}$ & $\begin{array}{l}\text { Reaction } \\
\text { temperature }\end{array}$ & $\begin{array}{l}\text { Type } \\
\text { of } \\
\text { MNPs }\end{array}$ & Size $(\mathrm{nm})$ & $\begin{array}{l}\text { Mechanism/causative } \\
\text { agent }\end{array}$ & References \\
\hline Shewanella algae ATCC 51181 & Cell extract & Water & $\begin{array}{l}\text { Room } \\
\text { temperature }\end{array}$ & $\mathrm{Au}$ & $\begin{array}{l}9.6 \\
\text { spherical }\end{array}$ & ND & [108] \\
\hline Sargassum muticum & Cell extract & Water & $450{ }^{\circ} \mathrm{C}$ & $\mathrm{ZnO}$ & $30-57$ & ND & [110] \\
\hline Chlorococcum humicola & Cell extract & Water & $\begin{array}{l}\text { Room } \\
\text { temperature }\end{array}$ & $\mathrm{Ag}$ & 16 & ND & [111] \\
\hline Plectonema boryanum UTEX 485 & Cell extract & Water & $25-180{ }^{\circ} \mathrm{C}$ & $\mathrm{Pt}$ & $\begin{array}{l}\text { Spherical } \\
<300\end{array}$ & ND & [112] \\
\hline Sargassum bovinum & Cell extract & Water & $60^{\circ} \mathrm{C}$ & $\mathrm{Pd}$ & $5-10$ & ND & [113] \\
\hline Phormidium tenue NTDM05 & Cell extract & Water & $\begin{array}{l}\text { Not } \\
\text { mentioned }\end{array}$ & $\mathrm{CdS}$ & $5.1 \pm 0.2$ & $\begin{array}{l}\text { The C-phycoerythrin } \\
\text { pigment/ }\end{array}$ & [114] \\
\hline \multirow[t]{3}{*}{ Phormidium valderianum } & Cell extract & $\begin{array}{l}\text { Water } \\
\text { pH } 5.0\end{array}$ & $\begin{array}{l}\text { Room } \\
\text { temperature }\end{array}$ & $\mathrm{Au}$ & 15 & ND & [115] \\
\hline & & $\mathrm{pH} 7.0$ & & & $7.92-17$ & & \\
\hline & & $\mathrm{pH} 9.0$ & & & 13.78 & & \\
\hline Phormidium tепие & Cell culture & $\mathrm{pH} 5.0$ & & & 14.84 & & \\
\hline \multicolumn{8}{|l|}{ Ulva intestinalis, } \\
\hline \multirow[t]{4}{*}{ Chlorella vulgaris } & $\begin{array}{l}\text { Algal extract } \\
\text { Fractionated } \\
\text { algal extract }\end{array}$ & Water & $\begin{array}{l}\text { Room } \\
\text { temperature }\end{array}$ & $\mathrm{Ag}$ & $\begin{array}{l}44 \pm 6 \\
48\end{array}$ & Proteins & {$[122]$} \\
\hline & $\begin{array}{l}\text { Modified algal } \\
\text { proteins heat } \\
\text { denatured }\end{array}$ & & & & 27 & & \\
\hline & $\begin{array}{l}\text { Modified algal } \\
\text { proteins urea- } \\
\text { denatured }\end{array}$ & & & & 26 & & \\
\hline & Amine-modified & & & & 29 & & \\
\hline Chlorella vulgaris & Cell extract & Water & $\begin{array}{l}\text { Room } \\
\text { temperature }\end{array}$ & $\mathrm{Au}$ & $\begin{array}{l}\text { 9-20 single- } \\
\text { crystalline }\end{array}$ & ND & {$[124]$} \\
\hline Chlorella pyrenoidusa & Cell extract & Water & $100{ }^{\circ} \mathrm{C}$ & $\mathrm{Au}$ & $\begin{array}{l}25-30 \\
\text { Spherical/ } \\
\text { icosahedral }\end{array}$ & ND & [125] \\
\hline Plectonema boryanum UTEX 485 & $\begin{array}{l}\text { Cyanobacteria } \\
\text { culture }\end{array}$ & Water & $25-100{ }^{\circ} \mathrm{C}$ & $\mathrm{Au}$ & $<10-25$ & ND & [126] \\
\hline Sargassum wightii & Cell extract & Water & $\begin{array}{l}\text { Room } \\
\text { temperature }\end{array}$ & $\mathrm{Au}$ & $8-12$ & ND & [127] \\
\hline Spirulina platensis IPPAS B-256 & Cell extract & Water & $\begin{array}{l}\text { Room } \\
\text { temperature }\end{array}$ & $\mathrm{Au}$ & $\begin{array}{l}20-30 \\
\text { Spherical }\end{array}$ & ND & [128] \\
\hline Shewanella algae & Cell culture & Water & $\begin{array}{l}\text { Room } \\
\text { temperature }\end{array}$ & $\mathrm{Au}$ & $10-20$ & ND & [129] \\
\hline $\begin{array}{l}\text { Pterocladia } \\
\text { capillacae }(P c), \text { Jania rubins }(\mathrm{Jr}), \\
\text { Ulva faciata }(\mathrm{Uf}), \text { and Colpmenia } \\
\text { sinusa }(\mathrm{Cs})\end{array}$ & Cell extract & Water & $70{ }^{\circ} \mathrm{C}$ & $\mathrm{Ag}$ & $7-20$ & ND & {$[23]$} \\
\hline $\begin{array}{l}\text { Chlorella vulgaris/Scendesmus } \\
\text { obliquus }\end{array}$ & Cell culture & Water & $\begin{array}{l}\text { Room } \\
\text { temperature }\end{array}$ & $\mathrm{Ag}$ & $\begin{array}{l}8.2 \pm 3 / \\
8.8 \pm 2\end{array}$ & ND & {$[130]$} \\
\hline $\begin{array}{l}\text { C. calcitrans, } \\
\text { C. salina, } \\
\text { I. galbana and } \\
\text { T. gracilis }\end{array}$ & Cell culture & Water & $\begin{array}{l}\text { Room } \\
\text { temperature }\end{array}$ & $\mathrm{Ag}$ & $53.1-71.9$ & ND & [131] \\
\hline
\end{tabular}


Table 5 continued

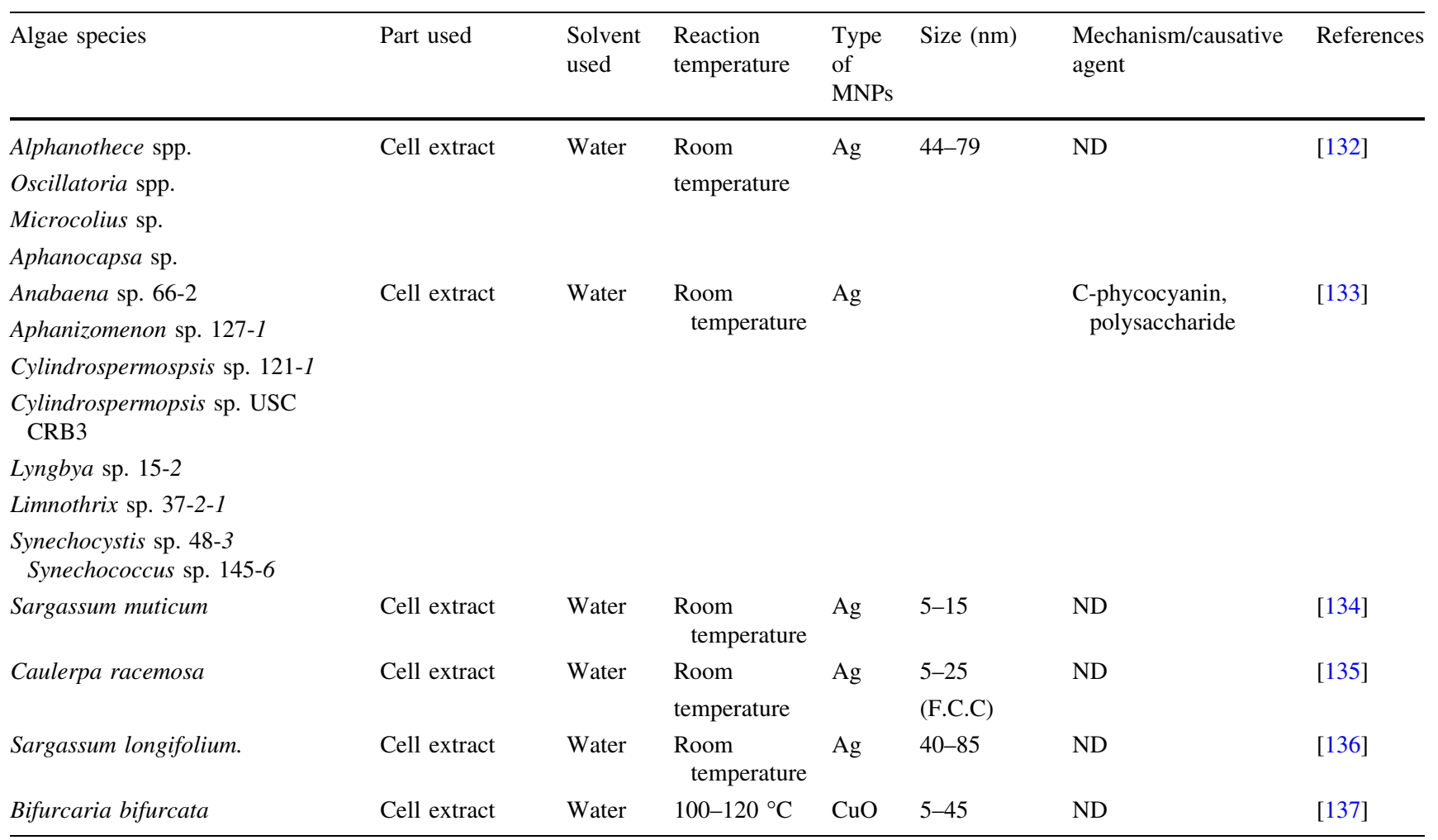

positive metal ions transportation into the cell wall by interaction with negative ions of the cell wall. Further, enzymes of cell wall reduce the metal ion into nanoparticles, and later, these nanoparticles diffuse across the cell wall of bacteria. In case of fungi, the extracellular production of nanoparticle is nitrate reductase-mediated synthesis in the presence of enzyme nitrate, which helps with bio-reduction of metal ions into nanoparticles [35]. Herein, a brief overview on the recent research of microbial synthesis of metallic nanoparticles is included.

\section{Bacteria mediated}

Bacterial cell wall plays a very important role; essential metals must percolate through the wall into the cytoplasm and be transferred back through wall meshwork for extracellular liberation. The cell wall composition of peptidoglycan provides polyanions for stoichiometric interaction between metal and chemical reactive groups of wall followed by inorganic deposition of metal. The wall with numerous potential metal binding sites can be altered by chemical reactions (anhydride treatment) for specific groups, such as amines and carboxyl groups, which convert positive charge to negative charge (an important step in metal binding process). Chemical modification on peptidoglycan of $B$. subtilis resulted in modification of carboxyl group of glutamic acid for easy metal penetration with profound metal deposition [140]. Once inside the cell, metal deposition can range from 20,000- to 40,000-folds over the extracellular concentration and also impart dipole moment to bacteria for orientation toward geomagnetic field. The crystalline and non-crystalline phases of particles are often influenced by the cellular intra- and extracellular environment and also with species having specific morphology of bacteria. The intracellular and extracellular mechanism of nanoparticle synthesis is represented in Fig. 2.

The mechanism of $\mathrm{Fe}_{3} \mathrm{O}_{4}$ crystal formation occurs within cells during the crystal growth mechanism in the presence of hydrates iron-oxide as precursor [141]. In the presence of cadmium ions in the growth medium, Klebsiella pneumoniae was able to form nanometer-sized $\mathrm{CdS}$ particles on cell surface. The surface characteristic of bacterial cell wall reflects the deposition of discrete quantum dots of $\mathrm{CdS}$, so-called bio-CdS for a possible biological membrane to protect against corrosion. Such synthesis overcomes the hazardous effect of $\mathrm{Cd}$ species and possess photochemical and photo-physical properties for possible bio-semiconductor applications [142]. Using 


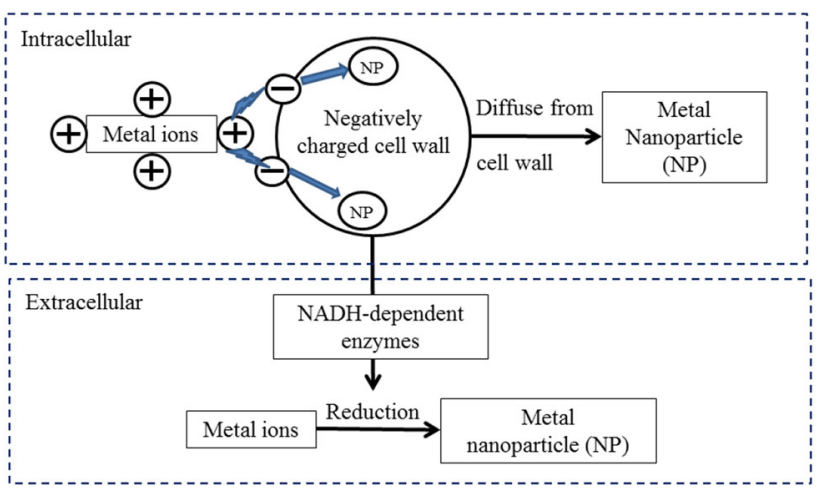

Fig. 2 Intracellular and extracellular syntheses of nanoparticles by bacteria

Pseudomonas stutzeri, an isolated strain from silver mine was able to produce cermet nanoparticle between the cell wall and the plasma membrane. The biosynthesized crystalline silver particles consist of organic carbon matrix with distinct shape and size. Subsequent treatment steps, such as heat, change in metal volume fraction and by providing effective medium for production can together tailor the optical properties. The biologically synthesized nanoparticles using low cost and relatively simple method possess properties complementary to conventional thin-film coating technologies. Such materials have useful technological application in optical filters and can also be used for efficient solar photothermal conversion into energy [143, 144]. The silver resistance of $P$. stutzeri enables pumping system of cellular efflux, binding proteins of cell surface with formation and accumulation of metal precipitate by metal flux and metal binding [144]. The tolerance of bacteria toward metal ions and formation of metal nanoparticles depends on physical and chemical growth parameters, such as particle size, $\mathrm{pH}$, temperature, culture time, composition of growth medium and growth in light or dark conditions. The biosynthesis of metal nanoparticles from metal-containing bacteria yield controlled optical and electrical properties with potential future application [144]. The nano-materials from bacteria can be completely harvested and have wide application in analytical chemistry, metal ion recovery, medical sector during rheumatology and drug delivery [145]. In the presence of $\mathrm{H}_{2}$ as elector donor with sulfate-reducing bacterium, the production of $\mathrm{Pd}$ (II)-Pd (0) was accelerated at maximum rate of $1.3-1.4 \mu \mathrm{mol} / \mathrm{min} /$ $\mathrm{mg}$ dry cells. The biological Pd possessed the property of chemical catalyst, which can be used for possible bioprocessing application during industrial wastewater processing for metal recovery by single-step [146]. The recovery of metals from environment by adsorption onto the bacteria biomass by bio-sorption process further results in bio-reduction of metals into nanoparticles. Therefore, bio-sorption coupled with bio-reduction for conversion of heavy metals waste into nanoparticles is increasingly interesting in the industrial synthesis of nanoparticles [147]. The biological synthesis of spherical platinum nanoparticles using living and non-living organisms offers green nanofactories, a viable alternative to standard chemical methods [112]. Surgical instruments made of titanium react with human serum causing the generation of cancer cells, but with biological eco-friendly approach using bacteria, the possible nano-titanium for future application in cancer chemotherapy and gene delivery can be emphasized [148]. The production of nanoparticles using various bacteria at various locations with different shape and size is presented in Table 6.

\section{Fungal mediated}

Rational synthesis of nanoparticles by fungi holds advantages over the bacteria. Using fungi, it is possible to synthesize nanoparticles with nanoscale dimension and with more tolerable monodispersity in comparison with those synthesized by bacteria. Fungi have potential strategies for extracellular synthesis of nanoparticle for greater commercial viability. Fusarium oxysporum in the presence of aqueous $\mathrm{AuCl}_{4}{ }^{-}$ions with $\mathrm{NADH}$-enzyme-mediated reaction releases reducing agents into the solution for the formation of gold nanoparticles. The synthesized nanoparticles show long-term stability in solution, due to the protein binding through linkage of cysteine and lysine residue. Because of this property, immobilization on matrices or thin-films for optoelectronic and nonlinear optical application is possible [149]. In comparison with other fungal species, $F$. oxysporum is capable of hydrolyzing never encountered metals and in the presence of $\mathrm{K}_{2} \mathrm{ZrF}_{6}$ aqueous solution, crystalline zirconia nanoparticles are formed. The fungus can also synthesize silica and titania nanoparticles in the presence of aqueous anionic complexes of $\mathrm{Si}$ and $\mathrm{Ti}$, respectively. The fungal biological system possesses regenerative capability with eco-friendly and energy-conserving nature for large-scale synthesis of metal nanoparticles for possible commercial viability [150-152]. F. oxysporum can carry out extracellular synthesis of $\mathrm{Au}-\mathrm{Ag}$ nanoparticles at varying molar fraction when exposed to equimolar solution of $\mathrm{AuCl}_{4}$ and $\mathrm{AgNO}_{3}$ [153], and in some cases it can also synthesize platinum nanoparticles through inter- and extracellular formation in the presence of hexachloroplatinic acid $\left(\mathrm{H}_{2} \mathrm{PtCl}_{6}\right)$ [154]. Various bacteria, fungi and yeasts isolated from soil and metal-rich dump samples were used to manipulate the size and shape of gold nanoparticles by altering the $\mathrm{pH}$ and temperature during growth conditions. Two fungi, Verticillium luteoalbum and isolate 6-3 produced variety of nanoparticle shape by varying the $\mathrm{pH}$, and with low 
Table 6 Representative examples of bacteria used for the green synthesis of different metallic nanoparticles

\begin{tabular}{lllll}
\hline Microorganisms & Nanoparticle & Localization/morphology & Size and shape & References \\
\hline Bacillus subtilis 168 & $\mathrm{Au}$ & Inside cell wall & $5-25 \mathrm{~nm}$, octahedral \\
Aquaspirillum magnetotacticum & $\mathrm{Fe}_{3} \mathrm{O}_{4}$ & Intracellular & $40-50 \mathrm{~nm}$, octahedral prism \\
Klebsiella pneumoniae & $\mathrm{CdS}$ & Cell surface & $5-200 \mathrm{~nm}$ & {$[140]$} \\
Pseudomonas stutzeri $\mathrm{AG} 259$ & $\mathrm{Ag}, \mathrm{Ag} 2 \mathrm{~S}$ & Periplasmic space & $<200 \mathrm{~nm}$, nano-crystals \\
Lactobacillus sp. & $\mathrm{Au}, \mathrm{Ag}, \mathrm{Au}-\mathrm{Ag}$ & Intracellular & $20-50 \mathrm{~nm}$, hexagonal/contour \\
Desulfovibrio desulfuricans & $\mathrm{Pd}$ & Cell surface & $\sim 50 \mathrm{~nm}$ & {$[141]$} \\
Corynebacterium sp. $\mathrm{SH} 09$ & $\mathrm{Ag}$ & Cell wall & $10-15 \mathrm{~nm}$ & {$[143,144]$} \\
P. boryanum UTEX 485 & $\mathrm{Pt}$ & Intracellular & $30-0.3 \mathrm{~nm}$, spherical, chains, dendritic \\
Lactobacillus $\mathrm{sp}$. & $\mathrm{Ti}$ & Intracellular & $40-60 \mathrm{~nm}$, Spherical
\end{tabular}

operating temperature, the size of nanoparticle can be controlled [139, 155]. Aspergillus flavus demonstrated synthesis of monodispersed silver nanoparticles with average particle size of $8.92 \mathrm{~nm}$, and it also possessed 'sil' gene in plasmids for reduction of silver ions for large-scale production [156]. C. versicolor, a white-rot fungus, produced silver nanoparticles, via intra and extracellular mode in the absence of surfactants and linking agents. The silver nanoparticles synthesized by fungus in the presence of glucose as stabilizing agents had potential applications as water-soluble metallic catalysts for living cells [157]. The production of nanoparticles using various fungi with different shapes and sizes is presented in Table 7.

\section{Virus mediated}

Bacteria and fungi have difficulty in synthesizing inorganic nano-crystals with required arrays over the nanoscale length. In such cases, use of protein cages, DNA recognizing linkers and surfactant assembled pathways has limitations. However, these limitations are addressed with engineered viruses with production of self-assemble/support semiconductor surfaces possessing highly orient quantum dots (QD) structures with mono-disperse shape and size along the length of nanoparticles. Using genetic selection and molecular cloning technique, the genetically engineered phage-based tobacco mosaic virus (TMV) produces nanoparticles of specific lengths, which can align and modify inorganic nano-crystals in 3D layered materials [158]. The fabrication of viral films can be stored for 7 months without bacterial infection and can be used for storage of high-density engineered DNA with wide applications in medicine [159, 160]. The production of nanoparticles using various viruses with different shapes and sizes is presented in Table 8 .

\section{Animal world and synthesis of metallic nanoparticle}

MNPs have several applications, such as antimicrobial by interacting with enzymes, proteins, and/or DNA to inhibit the cell division. Furthermore, the MNPs can present a wide range of toxicity, ranging from fungi to the humans. On the other hand, they also have biomedical applications including catheters, dental material, medical devices and implants, using cellulose acetate as a good candidate due to its hydrophilic, non-toxic, biodegradable, properties [161-163]. Different synthesis methods have been developed for impregnation of metallic nanoparticles in tissue graft and were summarized elsewhere [164, 165].

Biomedicine and nano-medicine offer possibilities to improve medical diagnosis and therapy, through the development of different biological molecules that generate no toxicity in the host tissues. On the other hand, the magnetic nanoparticles are used in cancer treatment, because they can be designed to affect tumors. In this sense, experiments with animal model facilitate the design of formulations with improved tissue distribution and establishing general guidelines for the effective design of nanoparticles with medical applications [161, 166-168]. There are few reports on the animal-mediated synthesis of MNPs. The most studied case is the silk fibroin, synthesized by arachnids and worms, such as Bombyx mori, which have a little catalytic and molecular recognition, so that they can be used as suture material [40, 139, 169-172].

\section{Animal-derived materials}

Recently, polymer nano-fibers have been reported to have unique properties as their specific surface area, small pore diameters and ability to act as a microbial barrier has been used for production of novel materials. The nano-materials are administered into the host to evaluate the cell reaction, 
Table 7 Representative examples of fungi used for the green synthesis of different metallic nanoparticles

\begin{tabular}{|c|c|c|c|c|}
\hline Fungal species & Nanoparticle & Localization/morphology & Size and shape & References \\
\hline Fusarium oxysporum & $\mathrm{Au}$ & Extracellular & 20-40 nm spherical, TRIANGULAR & [149] \\
\hline F. oxysporum & $\mathrm{Zr}$ & Extracellular & 3-11 nm quasi-spherical & {$[150]$} \\
\hline F. oxysporum & $\mathrm{Au}-\mathrm{Ag}$ & Extracellular & $8-14 \mathrm{~nm}$ & {$[153]$} \\
\hline F. oxysporum & $\begin{array}{l}\mathrm{Si} \\
\mathrm{Ti}\end{array}$ & Extracellular & $\begin{array}{l}\text { 5-15 nm, quasi-spherical } \\
6-13 \mathrm{~nm} \text {, spherical }\end{array}$ & {$[152]$} \\
\hline F. oxysporum & $\mathrm{Pt}$ & Extracellular & 10-50 triangle, hexagons, square, rectangles & {$[154]$} \\
\hline F. oxysporum & $\mathrm{BaTiO}_{3}$ & Extracellular & $4 \mathrm{~nm}$ & {$[151]$} \\
\hline V. luteoalbum and isolate $6-3$ & $\mathrm{Au}$ & Extracellular & $<10 \mathrm{~nm}$ spherical & {$[139,155]$} \\
\hline Aspergillus flavus & $\mathrm{Ag}$ & Extracellular & $8.9 \mathrm{~nm}$ & {$[156]$} \\
\hline Coriolus versicolor & $\mathrm{Ag}$ & Intracellular and extracellular & 25-75 nm, 444-491 nm spherical & {$[157]$} \\
\hline
\end{tabular}

Table 8 Representative examples of viruses used for the green synthesis of different metallic nanoparticles

\begin{tabular}{lllll}
\hline Virus type & Nanoparticle type & Localization/morphology & Size and shape & References \\
\hline Tobacco mosaic virus $(T M V)$ & $\mathrm{SiO}_{2}, \mathrm{CdS}, \mathrm{PbS}$ and $\mathrm{Fe}_{2} \mathrm{O}_{3}$ & Nano-tubes on surface & $\mathrm{ND}$ & [158] \\
M13 bacteriophage & $\mathrm{ZnS}, \mathrm{CdS}$ & $\mathrm{ND}$ & $560 \times 20$ nm quantum dot nano-wires & [159, 160] \\
\hline
\end{tabular}

such as growth characteristics, and their physiology. Many organisms could be a source of inorganic materials as the cases mentioned above. For example, unicellular organisms producing magnetite nanoparticles and multicellular organisms produce inorganic composite materials from simpler ones to build different structures, such as bones, shells and spicules.

\section{Silk proteins (fibroin and sericin) and spider silk}

Silk fibroin is produced by a variety of insects and spiders. It is a natural semicrystalline biopolymer, and the principal compounds in the silk fibroin are the amino acids, such as glycine, alanine and serine. The silk fibroin has been used in textile production and clinical sutures as its properties can support the attachment, proliferation and differentiation of primary cells. Further, their preparation is easy, including films, porous scaffolds, gels and mats [163]. The silk fibroin was used as material for tissue engineering for skin, bone, blood vessel, ligament and nerve tissue regeneration, because it is non-immunogenic and non-toxic material. Some research articles show that silk fibroin is biodegradable, but the degradation rate of silk fibroin is not yet clear [163, 173-182]. The silk production is a natural ability of some arachnids, such as spiders, including some fossil species. The spiders can produce different types of silk, such as non-sticky, dry, strong threads for the structure of their webs and sticky spiraling threads for capturing prey. The animal silk used commercially until date is the silkworm, Bombyx mori, because it has little catalytic and molecular recognition; hence, it is used in suture material. Other species produce silk during metamorphosis, and for example, the larvae of Hymenoptera produces silk in its adult stage. A South American tree ant directly produces silk from their glands located in the oral cavity. The larvae of Trichoptera produce silk through the building bags from sand grains or plant fragments [170-173, 177, 178, 181]. Several nano-composites were also produced using fibroin as component, as fibroin- $\mathrm{TiO}_{2}$ [183], nano-hydroxyapatite/ silk fibroin [184]. The obtained crystalline particles measured $100 \mathrm{~nm}$ in length. Also, sericin, which is discarded in wastewater of silk industries, can be used for production of NPs. There are techniques reported to recover it to further produce nano-sericin particles. The extracted sericin is reduced by rotation to obtain a concentrated sericin solution. The nano-sericin powder is obtained after ultrasonication for reduction of the particle size and lyophilization [185]. These fibers resist oxidation, present antibacterial activity, are biocompatible and are UV resistant, among other features [186]. Finally, spider nets also present adhesive nano-filaments that are able to trap preys by a sticky aqueous glycoprotein [187].

\section{Invertebrate mediated}

The mineralized biological materials found in sponges and starfishes show similar structure and composition to the mammalian tooth, which facilitates their use in the 
medicine field. The manipulation of biomaterials for stabilization of amorphous minerals and the formation of microstructures is an important field of research. The most common examples of these biomaterials are the hydroxyapatite and the bio-silica. The hydroxyapatite is a natural mineral form of calcium apatite, isolated from fish bone; the main compound is nano-sized collagenous and noncollagenous proteins; their biomedical applications include the safety, biocompatibility and osteo-conductivity of bone graft. On the other hand, the bio-silica or biogenic silica is glassy amorphous silica formed by many aquatic organisms, such as sponges, diatoms, radiolarians and choanoflagellates. The bio-silica is formed by the enzyme silicatein in sponges [188-192]. This process occurs by appositional layering of lamellae consisting of silica nanoparticles [193]. Nano-hydroxyapatite (HA), for instance, has been studied for medical applications, such as osteogenesis [194]. Gunduz developed a method to obtain nano-HA from corals by thermo-gravimetry [195]. This was further developed to combine the nano-HA with chitosan [196]. There are further examples on the synthesis of nanoparticles reported from different species of worms. For instance, the extracts of earthworms, Eisenia andrei, when reacted to $\mathrm{HAuCl}_{4}$ resulted in nano-red gold [192]. Another example is the production of $\mathrm{Ag}$ nanoparticles using a solution of marine worms (polychaeta). Such solution served as agent for reduction as well as stabilizer in the production of the nanoparticles starting from silver nitrate [197].

\section{Chitosan}

This peptide, derived from invertebrate chitin, has several applications. For example, chitosan nano-fibers with diameters of around 20-40 $\mathrm{nm}$ can be used for colorizing textiles. It can also prevent static when combined to polyester textiles. In medicine, it can be used as a nanocapsule for slow release of vaccines and cancer treatment [198, 199]. Moreover, Mahmoodian et al. characterized the behavior of a poly HEMA-chitosan-MWCNT nano-composite that can be used for industrial and pharmaceutical applications as a carrier of other compounds [200]. Nanochitosan can also be used for environmental applications such as removal of pollutants. For example, Mansur et al. described $\mathrm{ZnS} /$ chitosan nano-photocatalysts of less than $4 \mathrm{~nm}$ for photodegradation of dangerous organic contaminants that can be found in wastewater as well as further environmentally friendly applications [201]. Furthermore, Sahab et al. prepared chitosan-poly-acrylic acid (PAA) nanoparticles of $50 \mathrm{~nm}$. This compound showed antifungal activity for 3 species (Fusarium oxysporum, F. solani and Aspergilus terreus) and inhibits egg deposition of different insect species as Aphis gossypii and Callosobruchus maculatus which usually affects soybean crops [202]. Another promising application was described by Salah et al. studied the removal of cadmium from wastewater using nano-sized hydroxyapatite/chitosan composite sorbents. It showed adsorption efficiency of around $122 \mathrm{mg} / \mathrm{g}$ [203]. Magnetic graphene/chitosan proved to be useful to remove organic dyes since the large number of hydroxyl and amino groups of chitosan together with the magnetism of $\mathrm{Fe}_{3} \mathrm{O}_{4}$ exhibited good adsorption for certain organic dyes [204]. Similarly, bentonite-chitosan nano-composites can adsorb and remove synthetic dyes with great efficiency [205]. More recently, a composite of $\mathrm{TiO}_{2}$ and chitosan was described to be efficient in the removal of organic pollutants from waste waters and at the same time, it retains a large proportion of its photocatalytic properties after 10 cycles [206]. Nano-ZnS quantum dots with chitosan have a similar applicability under UV radiation [201].

\section{Pros and cons of biological synthesis of metallic nanoparticles}

\section{Biological synthesis versus chemical synthesis}

The classical physical methods for the synthesis of nanoparticles include ball milling, thermal evaporation, lithography and vapor phase preparation. The widely used chemical approaches are based on chemical solutions. These are chemical reduction, irradiation, electrolysis, pyrolysis and sol-gel processing. Previous studies on physical and chemical methods revealed that the physicochemical properties, such as size, morphology, stability and reactivity of the metal nanoparticles are strongly influenced by experimental conditions, kinetics of interaction between metal ions and reducing agents and the adsorption between stabilizing agent and metal nanoparticles. Thus, in both physical and chemical synthesis, the design parameters are optimized for size, morphology and stability properties [207]. The major biological process includes synthesis from plant extract and the use of different microbes, such as fungi, bacteria and yeast. The biosynthesis of metallic nanoparticles is the product of enzyme activities when the microbe grabs target ions from their environment and then transforms the metal ions into the element metal. This process can be either intracellular or extracellular [208]. All biological synthesis models of nanoparticles have been discussed in details in previous sections explaining the method and corresponding yields.

Chemical methods are the most widely used for the synthesis of metallic nanoparticles. Even though use of chemically produced nanoparticles is restricted in clinical and biomedical fields, since the synthesis procedure 
involves the use of several toxic chemical and nonpolar solvents. Some of these chemical processes involve the use of toxic chemicals in later stages as synthetic additives and capping agents $[209,210]$. Another major drawback of chemical methods is that these methods are energy and capital intensive. Further, use of toxic chemicals during the synthesis process will end up in environmental compartments, such as soil and water adding up the concern along with other toxic by-products. Hence, the research for ecofriendly and green methods for the synthesis of metallic nanoparticle resulted in biological synthesis of nanoparticles, albeit at lower yield in the current context. Nanoparticles can be synthesized from simple prokaryotic bacterial cells to eukaryotic fungi and plants [211] which makes it versatile. Unlike chemical processes, biological methods, as an alternative, consume no energy and are carried out in environmentally favorable conditions. Also, the lack of toxic chemicals and solvents makes the process green, environmentally safe and eco-friendly. These 'bioproducts' are non-toxic and can be used for clinical and biomedical applications. The biological production of highly stable and well-characterized nanoparticles can be obtained by optimizing vital aspects, such as types of organisms, cell growth and enzyme activity, optical growth and reaction conditions and suitable biocatalyst. The enzymes secreted by microbes and the presence of proteins provide extractability for the biologically synthesized nanoparticles [208, 212] which is another step toward 'green synthesis' by the omission of stabilizing reagents. Moreover, biologically synthesized nanoparticles in comparison with chemically synthesized nanoparticles are polydispersed. The fundamental properties, such as electronic, optical, magnetic and catalytic properties, are controlled by the size and shape of the nanoparticles. Because of the ease of controllability in biological systems, biological synthesis of nanoparticles is a convenient method over chemical synthesis [213]. Nevertheless, the major drawback for the biological synthesis of nanoparticle is length of production as the microbes grow under natural conditions and synthesize the nanoparticle which must be addressed in the future studies.

\section{Biological synthesis and toxicity issue}

Concerns of toxic effect on target are minimal during biological synthesis of nanoparticles. The biosynthesized nanoparticles have broad range of applications, such as targeted drug delivery, cancer treatment, gene therapy and DNA analysis, antibacterial agents, biosensors, enhanced reaction rates, separation science and magnetic resonance imaging (MRI) [214] over chemical synthesis. This broad spectrum of applications cannot be achieved by chemical synthesis because of the use of hazardous chemicals during the preparation. In biological synthesis of metallic nanoparticles, use of hazardous chemicals, such as organic solvents and inorganic salts, is minimal which makes the process 'green.' Nevertheless, at least in few situations, such as synthesis and extraction, under non-aqueous environment, it is impossible to avoid the use of organic solvents. Hence, feasibility of the use of alternative green solvents, such as water, must be investigated [215].

\section{Environmental issues}

Nanoparticles can have environmental concern due to their toxicity toward many organisms, including humans. Since time immemorial, humans and other organisms have always been exposed to tiny particles from dust storms, volcanic ash and other natural processes. Even though the past century remarked a rapid growth in production of anthropogenic nanoparticles owing to industrial revolution, in recent years, nanoparticles have been under limelight in environmental pollution arena because of synthetic/engineered nanoparticles.

For most of the organisms, few vital organs are in constant contact with the environment in which they live. For example, in case of human or else human beings, skin, lungs and the gastrointestinal tract are always exposed to the environment. When compared with skin, the lungs and gastrointestinal tract are more vulnerable to NPs. Because of its nano-size, NPs can translocate from the entry ports into the circulatory and lymphatic systems, and ultimately to body tissues and organs. Some nanoparticles produce irreversible damage to cells by oxidative stress and/or organelle injury and the extent of which depends on the size and composition of the NPs [216-218]. The toxicity of metallic nanoparticles can be due to various reasons, such as dose, size, surface area of nanoparticles, concentration, particle chemistry and crystalline structure, aspect ratio and surface coating and functionalization [217]. It is also very important to recognize that not all nanoparticles are toxic and that toxicity depends on at least chemical composition and shape in addition to simply size and particle aging. Even though, many types of nanoparticles do not exhibit any toxic effects $[219,220]$ and few can be rendered nontoxic [221], still others have beneficial health effects [222, 223]. Also, along with simple classifications of physical behavior (and therefore toxicity), emphasis must be given to the study of toxicology of each material, in addition to particle aging so as to obtain accurate information to aid future policy and regulatory processes.

\section{Future perspective(s)}

Biological synthesis of nanoparticles is a comparatively new idea and in developmental stage. The newly developing field is encountering initial start-up problems, in 
particular with shape, size and size distribution, control of crystal growth and stability and aggregation of the synthesized nanoparticles [214]. These underlying problems are more general in nanoparticle synthesis; however, more attention is drawn toward biological synthesis as it is considered to be green and futuristic approach. Some salient points of biological synthesis comprise the fat that:

(1) The mechanistic aspects of the biologically synthesized nanoparticles were not clearly understood. Thus, future studies must concentrate on the enzymatic mechanisms and proteins responsible for nanoparticle synthesis. In addition, the properties of the synthesized nanoparticles must be studied systematically in comparison with their chemical counterparts.

(2) Another relatively unexplored area is the downstream processing of MNPs. This process includes the purification of synthesized nanoparticles from any impurities which are present, such as the microbes itself. It is to be noted that most of the chemical purification processes must be avoided to keep the nanoparticles non-toxic. Physical processes, such as centrifugation, freeze-thawing, heating processes, ultrasound and osmotic shock can be investigated.

(3) Until date, the biological synthesis of metallic nanoparticles has been mostly carried out at laboratory scale. The industrial scale optimization is required for large-scale production. With proper optimized conditions and suitable microorganisms, these 'bio-nano-factories' can produce stable nanoparticles with well-defined sizes, composition and morphology. The commercialized processes will result in a non-toxic biological system capable of producing metallic nanoparticles which will be another milestone toward sustainable development.

(4) Cost effectiveness is another factor that must be addressed to make the process sustainable. The economic analyses must be carried out in comparison with the widely used chemical methods. As mentioned earlier, the large-scale production of nanoparticles via biosynthesis is yet to be performed to cope with industrial feasibility. For example, in chemical synthesis, the lion's share is coming from the cost of consumable chemicals, such as reducing agents, salts and stabilizing agents, among others. As in the case of biological synthesis, major expense will come from metal salt and the media for microbial growth. In this case, recyclable waste materials can be an option to reduce the expenses.
This can be a sustainable approach with valueaddition and recycling of waste.

(5) Future studies must emphasize rapid synthesis of nanoparticles. It is interesting that some research is already ongoing in this direction [212].

(6) Recent developments have suggested that principles of green chemistry can be effectively applied for the biological synthesis of nanoparticles [215], and this will be a giant leap toward sustainability and 'green future.'

Acknowledgements Financial support from the Natural Sciences and Engineering Research Council of Canada (NSERC, Discovery Grant 355254, CRD grant), MAPAQ (No. 809051), FRQNT Equipe and Ministère des Relations Internationales du Québec (coopération Paraná-Québec 2010-2012; Quebec-Vietnam 2012-2015) are sincerely acknowledged.

\section{References}

1. Ahluwalia V (2006) Green chemistry: environmentally benign reaction. Ane Books Pvt Ltd, New Delhi

2. Anastas PT, Perosa A, Selva M (2014) Handbook of green chemistry, green processes, green nanoscience, vol 8. Wiley, Hoboken

3. Anastas PT, Horváth IT (2011) Green chemistry for a sustainable future. Wiley-Blackwell, Hoboken

4. Feynman RP (1960) There's plenty of room at the bottom. Eng Sci 23(5):22-36

5. Biswas P, Wu C-Y (2005) Nanoparticles and the environment. J Air Waste Manag Assoc 55(6):708-746

6. Bystrzejewska-Piotrowska G, Golimowski J, Urban PL (2009) Nanoparticles: their potential toxicity, waste and environmental management. Waste Manag 29(9):2587-2595

7. Christian P et al (2008) Nanoparticles: structure, properties, preparation and behaviour in environmental media. Ecotoxicology 17(5):326-343

8. Gottschalk F, Nowack B (2011) The release of engineered nanomaterials to the environment. $J$ Environ Monit 13(5):1145-1155

9. Klaine SJ et al (2008) Nanomaterials in the environment: behavior, fate, bioavailability, and effects. Environ Toxicol Chem 27(9):1825-1851

10. Lead JR, Wilkinson KJ (2006) Aquatic colloids and nanoparticles: current knowledge and future trends. Environ Chem 3(3):159-171

11. Moore M (2006) Do nanoparticles present ecotoxicological risks for the health of the aquatic environment? Environ Int 32(8):967-976

12. Nowack B, Bucheli TD (2007) Occurrence, behavior and effects of nanoparticles in the environment. Environ Pollut 150(1):5-22

13. Nowack B et al (2012) Potential scenarios for nanomaterial release and subsequent alteration in the environment. Environ Toxicol Chem 31(1):50-59

14. O’Brien N, Cummins E (2010) Ranking initial environmental and human health risk resulting from environmentally relevant nanomaterials. J Environ Sci Health A 45(8):992-1007

15. Shan G et al (2009) Applications of nanomaterials in environmental science and engineering: review. Pract Period Hazard Toxic Radioact Waste Manag 13(2):110-119 
16. Wiesner MR et al (2006) Assessing the risks of manufactured nanomaterials. ACS Publications, Washington, DC

17. Auffan M et al (2009) Towards a definition of inorganic nanoparticles from an environmental, health and safety perspective. Nat Nanotechnol 4(10):634-641

18. Lovley DR et al (1987) Anaerobic production of magnetite by a dissimilatory iron-reducing microorganism. Nature 330(6145):252-254

19. Shameli K et al (2012) Green biosynthesis of silver nanoparticles using Curcuma longa tuber powder. Int $\mathrm{J}$ Nanomedicine 2012(7):5603-5610

20. Yang X et al (2010) Green synthesis of palladium nanoparticles using broth of Cinnamomum camphora leaf. J Nanoparticle Res 12(5):1589-1598

21. Joglekar S et al (2011) Novel route for rapid biosynthesis of lead nanoparticles using aqueous extract of Jatropha curcas L. latex. Mater Lett 65(19):3170-3172

22. St. Angelo SK, Hartz EL (2012) Ginkgo as a green reducing agent for gold nanoparticles and nanoplatelets. Int J Green Nanotechnol 4(2):111-116

23. El-Rafie H, El-Rafie M, Zahran M (2013) Green synthesis of silver nanoparticles using polysaccharides extracted from marine macro algae. Carbohyd Polym 96(2):403-410

24. Das RK, Borthakur BB, Bora U (2010) Green synthesis of gold nanoparticles using ethanolic leaf extract of Centella asiatica. Mater Lett 64(13):1445-1447

25. Das $S$ et al (2013) Biosynthesized silver nanoparticles by ethanolic extracts of Phytolacca decandra, Gelsemium sempervirens, Hydrastis canadensis and Thuja occidentalis induce differential cytotoxicity through G2/M arrest in A375 cells. Colloids Surf B 101:325-336

26. Mary SC et al (2013) Larvicidal potential of silver nanoparticles synthesized using Adiantum capillus verenis against Anopheles stephensi (diptera; culicidae). Int J Curr Trop Med Health Res 1:09-18

27. Aramwit P et al (2014) Green synthesis of silk sericin-capped silver nanoparticles and their potent anti-bacterial activity. Nanoscale Res Lett 9(1):79

28. Cho KY et al (2003) Preparation of self-assembled silk sericin nanoparticles. Int J Biol Macromol 32(1):36-42

29. Singh A, Hede S, Sastry M (2007) Spider silk as an active scaffold in the assembly of gold nanoparticles and application of the gold-silk bioconjugate in vapor sensing. Small 3(3):466-473

30. Tokarek K et al (2013) Green synthesis of chitosan-stabilized copper nanoparticles. Eur J Inorg Chem 2013(28):4940-4947

31. Balavandy SK, Shameli K, Abidin ZZ (2015) Rapid and green synthesis of silver nanoparticles via sodium alginate media. Int $\mathbf{J}$ Electrochem Sci 10(1):486-497

32. Han L et al (2013) Invertebrate water extracts as biocompatible reducing agents for the green synthesis of gold and silver nanoparticles. Nat Prod Commun 8(8):1149-1152

33. Dhillon GS et al (2012) Green approach for nanoparticle biosynthesis by fungi: current trends and applications. Crit Rev Biotechnol 32(1):49-73

34. Zhang X (2011) Application of microorganisms in biosynthesis nanomaterials - a review. Wei sheng wu xue bao = Acta Microbiologica Sinica 51(3):297-304

35. Hulkoti NI, Taranath T (2014) Biosynthesis of nanoparticles using microbes-a review. Colloids Surf B 121:474-483

36. Narayanan KB, Sakthivel N (2010) Biological synthesis of metal nanoparticles by microbes. Adv Coll Interface Sci 156(1):1-13

37. Mandal D et al (2006) The use of microorganisms for the formation of metal nanoparticles and their application. Appl Microbiol Biotechnol 69(5):485-492
38. Iravani S (2014) Bacteria in nanoparticle synthesis: current status and future prospects. Int Sch Res Not 2014:3593161-359316-18

39. Das RK, Brar SK (2013) Plant mediated green synthesis: modified approaches. Nanoscale 5(21):10155-10162

40. Thakkar KN, Mhatre SS, Parikh RY (2010) Biological synthesis of metallic nanoparticles. Nanomed Nanotechnol Biol Med $6(2): 257-262$

41. Kharissova OV et al (2013) The greener synthesis of nanoparticles. Trends Biotechnol 31(4):240-248

42. Mittal AK, Chisti Y, Banerjee UC (2013) Synthesis of metallic nanoparticles using plant extracts. Biotechnol Adv 31(2):346-356

43. Iravani S (2011) Green synthesis of metal nanoparticles using plants. Green Chem 13(10):2638-2650

44. Petrovska BB (2012) Historical review of medicinal plants' usage. Pharmacogn Rev 6(11):1

45. Shukla VK et al (2012) Green synthesis of nanosilver as a sensor for detection of hydrogen peroxide in water. J Hazard Mater 213:161-166

46. Nune SK et al (2009) Green nanotechnology from tea: phytochemicals in tea as building blocks for production of biocompatible gold nanoparticles. J Mater Chem 19(19):29122920

47. Shankar SS, Ahmad A, Sastry M (2003) Geranium leaf assisted biosynthesis of silver nanoparticles. Biotechnol Prog 19(6):1627-1631

48. Santhoshkumar T et al (2011) Synthesis of silver nanoparticles using Nelumbo nucifera leaf extract and its larvicidal activity against malaria and filariasis vectors. Parasitol Res 108(3):693-702

49. Premanand G et al (2016) Nelumbo nucifera leaf extract mediated synthesis of silver nanoparticles and their antimicrobial properties against some human pathogens. Appl Nanosci 6(3):409-415

50. Shankar SS et al (2005) Controlling the optical properties of lemongrass extract synthesized gold nanotriangles and potential application in infrared-absorbing optical coatings. Chem Mater 17(3):566-572

51. Armendariz V et al (2004) Size controlled gold nanoparticle formation by Avena sativa biomass: use of plants in nanobiotechnology. J Nanopart Res 6(4):377-382

52. Medda $\mathrm{S}$ et al (2015) Biosynthesis of silver nanoparticles from Aloe vera leaf extract and antifungal activity against Rhizopus sp. and Aspergillus sp. Appl Nanosci 5(7):875-880

53. Chandran SP et al (2006) Synthesis of gold nanotriangles and silver nanoparticles using Aloevera plant extract. Biotechnol Prog 22(2):577-583

54. Huang $\mathbf{J}$ et al (2007) Biosynthesis of silver and gold nanoparticles by novel sundried Cinnamomum camphora leaf. Nanotechnology 18(10):105104

55. Gardea-Torresdey JL et al (2003) Alfalfa sprouts: a natural source for the synthesis of silver nanoparticles. Langmuir 19(4):1357-1361

56. Subhankari I, Nayak P (2013) Synthesis of copper nanoparticles using Syzygium aromaticum (Cloves) aqueous extract by using green chemistry. World J Nano Sci Technol 2(1):14-17

57. Nasrollahzadeh M, Sajadi SM, Khalaj M (2014) Green synthesis of copper nanoparticles using aqueous extract of the leaves of Euphorbia esula L and their catalytic activity for ligand-free Ullmann-coupling reaction and reduction of 4-nitrophenol. RSC Adv 4(88):47313-47318

58. Hoag GE et al (2009) Degradation of bromothymol blue by 'greener'nano-scale zero-valent iron synthesized using tea polyphenols. J Mater Chem 19(45):8671-8677 
59. Wang $\mathrm{T}$ et al (2014) Green synthesis of Fe nanoparticles using eucalyptus leaf extracts for treatment of eutrophic wastewater. Sci Total Environ 466:210-213

60. Sangeetha G, Rajeshwari S, Venckatesh R (2011) Green synthesis of zinc oxide nanoparticles by aloe barbadensis miller leaf extract: structure and optical properties. Mater Res Bull 46(12):2560-2566

61. Suresh J et al (2014) Green synthesis of magnesium oxide nanoparticles. In: Advanced materials research, Trans Tech Publications

62. Yuvakkumar R et al (2014) Rambutan (Nephelium lappaceum L.) peel extract assisted biomimetic synthesis of nickel oxide nanocrystals. Mater Lett 128:170-174

63. Sushma NJ et al (2016) Facile approach to synthesize magnesium oxide nanoparticles by using Clitoria ternatea-characterization and in vitro antioxidant studies. Appl Nanosci $6(3): 437-444$

64. Alshatwi AA, Athinarayanan J, Subbarayan PV (2015) Green synthesis of platinum nanoparticles that induce cell death and G2/M-phase cell cycle arrest in human cervical cancer cells. J Mater Sci Mater Med 26(1):1-9

65. Raut RW et al (2013) Rapid biosynthesis of platinum and palladium metal nanoparticles using root extract of Asparagus racemosus Linn. Adv Mat Lett 4(8):650-654

66. Safaepour M et al (2009) Green synthesis of small silver nanoparticles using geraniol and its cytotoxicity against fibrosarcoma-wehi 164. Avicenna J Med Biotechnol $1(2): 111-115$

67. D'Britto V et al (2012) Medicinal plant extracts used for blood sugar and obesity therapy shows excellent inhibition of invertase activity: synthesis of nanoparticles using this extract and its cytotoxic and genotoxic effects. Int $\mathrm{J}$ life Sci Pharma Res 2:61-74

68. Alkilany AM, Murphy CJ (2010) Toxicity and cellular uptake of gold nanoparticles: what we have learned so far? J Nanopart Res 12(7):2313-2333

69. Chithrani BD, Ghazani AA, Chan WC (2006) Determining the size and shape dependence of gold nanoparticle uptake into mammalian cells. Nano Lett 6(4):662-668

70. Chen Y-S et al (2009) Assessment of the in vivo toxicity of gold nanoparticles. Nanoscale Res Lett 4(8):858

71. Patra HK et al (2007) Cell selective response to gold nanoparticles. Nanomed Nanotechnol Biol Med 3(2):111-119

72. Lewinski N, Colvin V, Drezek R (2008) Cytotoxicity of nanoparticles. Small 4(1):26-49

73. Murphy CJ et al (2008) Gold nanoparticles in biology: beyond toxicity to cellular imaging. Acc Chem Res 41(12):1721-1730

74. Vanaja M et al (2013) Kinetic study on green synthesis of silver nanoparticles using Coleus aromaticus leaf extract. Adv Appl Sci Res 4(3):50-55

75. Mishra PM et al (2014) Biomimetic synthesis of silver nanoparticles by aqueous extract of Cinnamomum tamala leaves: optimization of process variables. Nanosci Nanotechnol Lett 6(5):409-414

76. Song JY, Kwon E-Y, Kim BS (2010) Biological synthesis of platinum nanoparticles using Diopyros kaki leaf extract. Bioprocess Biosyst Eng 33(1):159

77. Das RK, Gogoi N, Bora U (2011) Green synthesis of gold nanoparticles using Nyctanthes arbortristis flower extract. Bioprocess Biosyst Eng 34(5):615-619

78. Song JY, Jang H-K, Kim BS (2009) Biological synthesis of gold nanoparticles using Magnolia kobus and Diopyros kaki leaf extracts. Process Biochem 44(10):1133-1138

79. Van den Berg A et al (1995) Curcacycline A-a novel cyclic octapeptide isolated from the latex of Jatropha curcas L. FEBS Lett 358(3):215-218
80. Insanu M, Anggadiredja J, Kayser O (2012) Curcacycline A and B-new pharmacological insights to an old drug. Int J Appl Res Nat Prod 5(2):26-34

81. Sharma NC et al (2007) Synthesis of plant-mediated gold nanoparticles and catalytic role of biomatrix-embedded nanomaterials. Environ Sci Technol 41(14):5137-5142

82. Cirtiu CM, Dunlop-Briere AF, Moores A (2011) Cellulose nanocrystallites as an efficient support for nanoparticles of palladium: application for catalytic hydrogenation and Heck coupling under mild conditions. Green Chem 13(2):288-291

83. Manceau A et al (2008) Formation of metallic copper nanoparticles at the soil-root interface. Environ Sci Technol 42(5):1766-1772

84. Iravani S, Zolfaghari B (2013) Green synthesis of silver nanoparticles using Pinus eldarica bark extract. BioMed Res Int 2013:639725-1-639725-5. doi:10.1155/2013/639725

85. Velmurugan $P$ et al (2013) Pine cone-mediated green synthesis of silver nanoparticles and their antibacterial activity against agricultural pathogens. Appl Microbiol Biotechnol 97(1):361-368

86. Coccia F et al (2012) One-pot synthesis of lignin-stabilised platinum and palladium nanoparticles and their catalytic behaviour in oxidation and reduction reactions. Green Chem 14(4):1073-1078

87. Song JY, Kim BS (2009) Rapid biological synthesis of silver nanoparticles using plant leaf extracts. Bioprocess Biosyst Eng 32(1):79

88. Arundoss T et al (2013) A novel approach for the synthesis and characterization of ginkgo biloba gold nanoparticles- an alternative approach to chemical synthesis. Asian J Sci Technol 4(10): 140-144

89. Jha AK, Prasad K (2010) Green synthesis of silver nanoparticles using Cycas leaf. Int $\mathrm{J}$ Green Nanotechnol Phys Chem 1(2):P110-P117

90. Huang $\mathrm{J}$ et al (2008) Continuous-flow biosynthesis of silver nanoparticles by lixivium of sundried Cinnamomum camphora leaf in tubular microreactors. Ind Eng Chem Res 47(16):6081-6090

91. Jha AK et al (2009) Plant system: nature's nanofactory. Colloids Surf B 73(2):219-223

92. Noruzi M, Zare D, Davoodi D (2012) A rapid biosynthesis route for the preparation of gold nanoparticles by aqueous extract of cypress leaves at room temperature. Spectrochim Acta A Mol Biomol Spectrosc 94:84-88

93. Nasrollahzadeh M, Mohammad S (2015) Sajadi, Green synthesis of copper nanoparticles using Ginkgo biloba L. leaf extract and their catalytic activity for the Huisgen $[3+2]$ cycloaddition of azides and alkynes at room temperature. J Colloid Interface Sci 457:141-147

94. Kalpana D et al (2014) Green biosynthesis of silver nanoparticles using Torreya nucifera and their antibacterial activity. Arab J Chem 2014:1-11

95. Johnson I, Prabu HJ (2015) Green synthesis and characterization of silver nanoparticles by leaf extracts of Cycas circinalis, Ficus amplissima, Commelina benghalensis and Lippia nodiflora. Int Nano Lett 5(1):43-51

96. De Britto AJ, Gracelin DHS, Kumar PBJR (2012) Biogenic silver nanoparticles by Adiantum caudatum and their antibacterial activity. Int J Univ Pharm Life Sci 2(4):92-98

97. Sant DG et al (2013) Adiantum philippense L. frond assisted rapid green synthesis of gold and silver nanoparticles. J Nanoparticles 2013:182320-1-182320-9

98. Bhor G et al (2014) Synthesis of silver nanoparticles using leaflet extract of Nephrolepi sexaltata L. and evaluation antibacterial activity against human and plant pathogenic bacteria. Asian J Pharm Technol Innov 2(7) 
99. Santhoshkumar S, Nagarajan N (2014) Biological synthesis of silver nanoparticles of adiantum capillus-veneris L. and their evaluation of antibacterial activity against human pathogenic bacteria. Int J Pharma Sci Res 59:5511-5518

100. Kunjiappan S, Bhattacharjee C, Chowdhury R (2015) Hepatoprotective and antioxidant effects of Azolla microphylla based gold nanoparticles against acetaminophen induced toxicity in a fresh water common carp fish (Cyprinus carpio L.). Nanomedicine J 2(2):88-110

101. Singh P (2013) A simple, rapid, and green synthesis of capped gold nanospheres and nanorods using aqueous extract of azolla. Int J Green Nanotechnol 1:1-5

102. Korbekandi $\mathrm{H}$ et al (2014) Green biosynthesis of silver nanoparticles using Azolla pinnata whole plant hydroalcoholic extract. Green Process Synth 3(5):365-373

103. Asakawa Y, Ludwiczuk A, Nagashima F (2013) Phytochemical and biological studies of bryophytes. Phytochemistry 91:52-80

104. Acharya K, Sarkar J (2014) Bryo-synthesis of gold nanoparticles. Int J Pharm Sci Rev Res 29(1):82-86

105. Srivastava A et al (2011) Plant mediated synthesis of silver nanoparticles using a bryophyte: Fissidens minutus and its antimicrobial activity. Int J Eng Sci Technol 3(12):8342-8347

106. Kulkarni A et al (2012) Phytofabrication of silver nanoparticles from a novel plant source and its application. Int J Biol Pharm Res 3:417-421

107. Kulkarni AP et al (2011) Plant mediated synthesis of silver nanoparticles-tapping the unexploited sources. J Nat Prod Plant Resour 1(4):100-107

108. Sau TK, Murphy CJ (2004) Room temperature, high-yield synthesis of multiple shapes of gold nanoparticles in aqueous solution. J Am Chem Soc 126(28):8648-8649

109. Castro L et al (2013) Biological synthesis of metallic nanoparticles using algae. Nanobiotechnology IET 7(3):109-116

110. Azizi S et al (2014) Green biosynthesis and characterization of zinc oxide nanoparticles using brown marine macroalga Sargassum muticum aqueous extract. Mater Lett 116:275-277

111. Jena $J$ et al (2013) Biosynthesis and characterization of silver nanoparticles using microalga Chlorococcum humicola and its antibacterial activity. Int $\mathbf{J}$ Nanomater Biostruct 3:1-8

112. Lengke MF, Fleet ME, Southam G (2006) Synthesis of platinum nanoparticles by reaction of filamentous cyanobacteria with platinum (IV)-chloride complex. Langmuir 22(17):7318-7323

113. Momeni S, Nabipour I (2015) A simple green synthesis of palladium nanoparticles with sargassum alga and their electrocatalytic activities towards hydrogen peroxide. Appl Biochem Biotechnol 176:1-13

114. MubarakAli D et al (2012) Synthesis and characterization of $\mathrm{CdS}$ nanoparticles using C-phycoerythrin from the marine cyanobacteria. Mater Lett 74:8-11

115. Parial D et al (2012) Screening of different algae for green synthesis of gold nanoparticles. Eur J Phycol 47(1):22-29

116. Chakraborty $\mathrm{N}$ et al (2009) Biorecovery of gold using cyanobacteria and an eukaryotic alga with special reference to nanogold formation-a novel phenomenon. J Appl Phycol 21(1): 145

117. Luangpipat $\mathrm{T}$ et al (2011) Gold nanoparticles produced in a microalga. J Nanopart Res 13(12):6439-6445

118. Govindaraju K et al (2009) Extracellular synthesis of silver nanoparticles by a marine alga, Sargassum wightii Grevilli and their antibacterial effects. J Nanosci Nanotechnol 9(9):5497-5501

119. Senapati $S$ et al (2012) Intracellular synthesis of gold nanoparticles using alga Tetraselmis kochinensis. Mater Lett 79:116-118

120. Mata Y et al (2009) Gold (III) biosorption and bioreduction with the brown alga Fucus vesiculosus. J Hazard Mater 166(2):612-618
121. Ali DM et al (2011) Biosynthesis and characterization of silver nanoparticles using marine cyanobacterium, Oscillatoria willei NTDM01. Dig J Nanomater Biostructures 6:385-390

122. Xie J et al (2007) Silver nanoplates: from biological to biomimetic synthesis. ACS Nano 1(5):429-439

123. Roni M et al (2015) Characterization and biotoxicity of Hypnea musciformis-synthesized silver nanoparticles as potential ecofriendly control tool against Aedes aegypti and Plutella xylostella. Ecotoxicol Environ Saf 121:31-38

124. Xie $\mathbf{J}$ et al (2007) Identification of active biomolecules in the high-yield synthesis of single-crystalline gold nanoplates in algal solutions. Small 3(4):672-682

125. Oza G et al (2012) Facile biosynthesis of gold nanoparticles exploiting optimum $\mathrm{pH}$ and temperature of fresh water algae Chlorella pyrenoidusa. Adv Appl Sci Res 3(3):1405-1412

126. Lengke MF, Fleet ME, Southam G (2006) Morphology of gold nanoparticles synthesized by filamentous cyanobacteria from gold (I)-thiosulfate and gold (III)-chloride complexes. Langmuir 22(6):2780-2787

127. Singaravelu $G$ et al (2007) A novel extracellular synthesis of monodisperse gold nanoparticles using marine alga, Sargassum wightii Greville. Colloids Surf B 57(1):97-101

128. Kalabegishvili $\mathrm{T}$ et al (2012) Synthesis of gold nanoparticles by blue-green algae Spirulina platensis. In: Proceedings of the international conference nanomaterials: applications and properties, Sumy State University Publishing

129. Konishi $\mathrm{Y}$ et al (2004) Microbial synthesis of gold nanoparticles by metal reducing bacterium. Trans Mater Res Soc Jpn 29:2341-2343

130. El-Sheekh MM, El-Kassas HY (2013) Application of biosynthesized silver nanoparticles against a cancer promoter cyanobacterium, Microcystis aeruginosa. Asian Pac J Cancer Prev APJCP 15(16):6773-6779

131. Merin DD, Prakash S, Bhimba BV (2010) Antibacterial screening of silver nanoparticles synthesized by marine micro algae. Asian Pac J Trop Med 3(10):797-799

132. Sudha S, Jamanickam K, Rengaramanujam J (2013) Microalgae mediated synthesis of silver nanoparticles and their antibacterial activity against pathogenic bacteria. Indian J Exp Biol 52:393-399

133. Patel V et al (2015) Screening of cyanobacteria and microalgae for their ability to synthesize silver nanoparticles with antibacterial activity. Biotechnol Rep 5:112-119

134. Azizi S et al (2013) Biosynthesis of silver nanoparticles using brown marine macroalga, Sargassum muticum aqueous extract. Materials 6(12):5942-5950

135. Kathiraven T et al (2014) Green synthesis of silver nanoparticles using marine algae Caulerpa racemosa and their antibacterial activity against some human pathogens. Appl Nanosci 5(4):499-504

136. Rajeshkumar S et al (2014) Algae mediated green fabrication of silver nanoparticles and examination of its antifungal activity against clinical pathogens. Int J Metals 2014:692643-1-692643-8

137. Abboud Y et al (2014) Biosynthesis, characterization and antimicrobial activity of copper oxide nanoparticles (CONPs) produced using brown alga extract (Bifurcaria bifurcata). Appl Nanosci 4(5):571-576

138. Mohanpuria P, Rana NK, Yadav SK (2008) Biosynthesis of nanoparticles: technological concepts and future applications. J Nanopart Res 10(3):507-517

139. Gericke M, Pinches A (2006) Biological synthesis of metal nanoparticles. Hydrometallurgy 83(1):132-140

140. Beveridge T, Murray R (1980) Sites of metal deposition in the cell wall of Bacillus subtilis. J Bacteriol 141(2):876-887

141. Mann S, Frankel RB, Blakemore RP (1984) Structure, morphology and crystal growth of bacterial magnetite. Nature 310(5976):405 
142. Smith PR et al (1998) Photophysical and photochemical characterisation of bacterial semiconductor cadmium sulfide particles. J Chem Soc Faraday Trans 94(9):1235-1241

143. Joerger R, Klaus T, Granqvist C (2000) Biologically produced silver-carbon composite materials for optically functional thinfilm coatings. Adv Mater 12(6):407-409

144. Klaus $\mathrm{T}$ et al (1999) Silver-based crystalline nanoparticles, microbially fabricated. Proc Natl Acad Sci 96(24):13611-13614

145. Nair B, Pradeep T (2002) Coalescence of nanoclusters and formation of submicron crystallites assisted by Lactobacillus strains. Cryst Growth Des 2(4):293-298

146. Yong P et al (2002) Bioreduction and biocrystallization of palladium by Desulfovibrio desulfuricans NCIMB 8307. Biotechnol Bioeng 80(4):369-379

147. Zhang $\mathrm{H}$ et al (2005) Biosorption and bioreduction of diamine silver complex by Corynebacterium. J Chem Technol Biotechnol 80(3):285-290

148. Prasad K, Jha AK, Kulkarni A (2007) Lactobacillus assisted synthesis of titanium nanoparticles. Nanoscale Res Lett 2(5):248-250

149. Mukherjee P et al (2002) Extracellular synthesis of gold nanoparticles by the fungus Fusarium oxysporum. ChemBioChem 3(5):461-463

150. Bansal V et al (2004) Biosynthesis of zirconia nanoparticles using the fungus Fusarium oxysporum. J Mater Chem 14(22):3303-3305

151. Bansal V et al (2006) Room-temperature biosynthesis of ferroelectric barium titanate nanoparticles. J Am Chem Soc 128(36):11958-11963

152. Bansal V et al (2005) Fungus-mediated biosynthesis of silica and titania particles. J Mater Chem 15(26):2583-2589

153. Senapati $\mathrm{S}$ et al (2005) Extracellular biosynthesis of bimetallic $\mathrm{Au}-\mathrm{Ag}$ alloy nanoparticles. Small 1(5):517-520

154. Riddin T, Gericke M, Whiteley C (2006) Analysis of the interand extracellular formation of platinum nanoparticles by Fusarium oxysporum f. sp. lycopersici using response surface methodology. Nanotechnology 17(14):3482

155. Gericke M, Pinches A (2006) Microbial production of gold nanoparticles. Gold Bull 39(1):22-28

156. Vigneshwaran $\mathrm{N}$ et al (2007) Biological synthesis of silver nanoparticles using the fungus Aspergillus flavus. Mater Lett 61(6):1413-1418

157. Sanghi R, Verma P (2009) Biomimetic synthesis and characterisation of protein capped silver nanoparticles. Biores Technol 100(1):501-504

158. Shenton W et al (1999) Inorganic-organic nanotube composites from template mineralization of tobacco mosaic virus. Adv Mater 11(3):253-256

159. Lee S-W et al (2002) Ordering of quantum dots using genetically engineered viruses. Science 296(5569):892-895

160. Mao C et al (2003) Viral assembly of oriented quantum dot nanowires. Proc Natl Acad Sci 100(12):6946-6951

161. Rathner BD et al (2004) Biomaterials science: a multidisciplinary endeavor. In: Biomaterials science: An introduction to materials in medicine, 2nd edn. Elsevier, San Diego, pp 1-9

162. Quadros C et al (2013) Chitosan/carboxymethylcellulose/ionic liquid/Ag (0) nanoparticles form a membrane with antimicrobial activity. J Nanotechnol 2013:140273-1-140273-9

163. Zhao Z, Li Y, Xie M-B (2015) Silk fibroin-based nanoparticles for drug delivery. Int J Mol Sci 16(3):4880-4903

164. Alonso-Lemus I et al (2010) Metal nanoparticles supported on Al-MCM-41 via in situ aqueous synthesis. J Nanomater 2010:19

165. Teske SS, Detweiler CS (2015) The biomechanisms of metal and metal-oxide nanoparticles' interactions with cells. Int $\mathrm{J}$ Environ Res Public Health 12(2):1112-1134
166. Albanese A, Tang PS, Chan WC (2012) The effect of nanoparticle size, shape, and surface chemistry on biological systems. Annu Rev Biomed Eng 14:1-16

167. Bava A et al (2013) Heparin and carboxymethylchitosan metal nanoparticles: an evaluation of their cytotoxicity. BioMed Res Int 2013:314091-1-314091-10

168. Huang $\mathrm{K}$ et al (2014) Time-evolution contrast of target MRI using high-stability antibody functionalized magnetic nanoparticles: an animal model. J Nanomater 2014:1

169. Zhang $Y$ et al (2010) Antheraea pernyi silk fiber: a potential resource for artificially biospinning spider dragline silk. BioMed Res Int 2010:683962-1-683962-8

170. İde $S$ et al (2011) Structural characterization of a variety of spider silks from Turkey using different biophysical techniques. J Spectrosc 25(3-4):155-167

171. Yang M et al (2012) Preparation of porous scaffolds from silk fibroin extracted from the silk gland of bombyx mori (B. mori). Int J Mol Sci 13(6):7762-7775

172. Zhao H et al (2012) Comparison of gelation time and polyalcohol effect on hydrogels from domestic and wild silk fibroins. Adv Mater Sci Eng 2012:819464-1-819464-6

173. Cao Y, Wang B (2009) Biodegradation of silk biomaterials. Int J Mol Sci 10(4):1514-1524

174. Bai L et al (2012) Exploring the mechanism of microarteriogenesis in porous silk fibroin film. Int J Biomater 2012:262890$1-262890-6$

175. Dyakonov T et al (2012) Design and characterization of a silkfibroin-based drug delivery platform using naproxen as a model drug. J Drug Deliv 2012:490514-1-490514-10

176. Hu Y et al (2012) The relationship between secondary structure and biodegradation behavior of silk fibroin scaffolds. Adv Mater Sci Eng 2012:185905-1-185905-5

177. Krafft B, Cookson LJ (2012) The role of silk in the behaviour and sociality of spiders. Psyche J Entomol 2012:529564$1-529564-25$

178. Wu MH et al (2013) Coimmobilization of naringinases on silk fibroin nanoparticles and its application in food packaging. J Nanoparticles 2013:901401-1-901401-5

179. Srisuwan Y, Baimark Y (2013) Preparation of biodegradable silk fibroin/alginate blend films for controlled release of antimicrobial drugs. Adv Mater Sci Eng 2013:412458$1-412458-6$

180. Dou H, Zuo B (2014) Effect of sodium carbonate concentrations on the formation and mechanism of regenerated silk fibroin nanofibers by electrospinning. J Nanomater 2014:89

181. Li H et al (2014) Effect of thickness of HA-coating on microporous silk scaffolds using alternate soaking technology. BioMed Res Int 2014:637821-1-637821-8

182. Asha S, Sangappa Y, Ganesh S (2015) Tuning the refractive index and optical band gap of silk fibroin films by electron irradiation. J Spectrosc 2015:879296-1-879296-7

183. Feng X-X et al (2007) Preparation and characterization of novel nanocomposite films formed from silk fibroin and nano-TiO 2. Int J Biol Macromol 40(2):105-111

184. Wang $G$ et al (2008) Preparation of nano silk fibroin/hydroxyapatite biological composite by "one-step" method. Acta Materiae Compositae Sinica 6:027

185. Agrawal P, Bhushan S (2013) Preparation of sericin nano particles from waste of silk industry. Int $\mathrm{J}$ Sci Res 1(3):116-120

186. Zhang $X$ et al (2012) Fabrication of silk sericin nanofibers from a silk sericin-hope cocoon with electrospinning method. Int $\mathbf{J}$ Biol Macromol 50(2):337-347

187. Vollrath F (2006) Spider silk: thousands of nano-filaments and dollops of sticky glue. Curr Biol 16(21):R925-R927 
188. Stupp SI, Braun PV (1997) Molecular manipulation of microstructures: biomaterials, ceramics, and semiconductors. Science 277(5330):1242-1248

189. Green D et al (2002) The potential of biomimesis in bone tissue engineering: lessons from the design and synthesis of invertebrate skeletons. Bone 30(6):810-815

190. Tao Y et al (2007) XAFS studies of transition metal and halogen biomaterials in invertebrate tools. In: AIP conference proceedings, AIP

191. Vago R (2008) Beyond the skeleton: cnidarian biomaterials as bioactive extracellular microenvironments for tissue engineering. Organogenesis 4(1):18-22

192. Kim S-K (2017) Marine biomaterials: characterization, isolation and applications. CRC Press, Hoboken

193. Müller WE et al (2009) Bio-sintering processes in hexactinellid sponges: fusion of bio-silica in giant basal spicules from Monorhaphis chuni. J Struct Biol 168(3):548-561

194. Wang H et al (2007) Biocompatibility and osteogenesis of biomimetic nano-hydroxyapatite/polyamide composite scaffolds for bone tissue engineering. Biomaterials 28(22):3338-3348

195. Gunduz O (2014) A simple method of producing hydroxyapatite and tri calcium phosphate from coral (Pocillopora verrucosa). J Aust Ceram Soc 50(2):52-58

196. Li J et al (2007) Modulation of nano-hydroxyapatite size via formation on chitosan-gelatin network film in situ. Biomaterials 28(5):781-790

197. Singh R, Sahu SK, Thangaraj M (2014) Biosynthesis of silver nanoparticles by marine invertebrate (polychaete) and assessment of its efficacy against human pathogens. J Nanoparticles 2014:718240-1-718240-7

198. Wijesena RN et al (2015) A method for top down preparation of chitosan nanoparticles and nanofibers. Carbohyd Polym 117:731-738

199. Malathi B et al (2015) Immunopotentiating nano-chitosan as potent vaccine carter for efficacious prophylaxis of filarial antigens. Int J Biol Macromol 73:131-137

200. Mahmoodian $\mathrm{H}$ et al (2015) Enhanced removal of methyl orange from aqueous solutions by poly HEMA-chitosan-MWCNT nano-composite. J Mol Liq 202:189-198

201. Mansur H, Mansur A (2015) Nano-photocatalysts based on ZnS quantum dots/chitosan for the photodegradation of dye pollutants. In: IOP conference series: materials science and engineering, IOP Publishing

202. Sahab A et al (2015) Synthesis, antifungal and insecticidal potential of Chitosan (CS)-g-poly (acrylic acid)(PAA) nanoparticles against some seed borne fungi and insects of soybean. Synthesis 8(2):589-598

203. Salah TA et al (2014) Development of nano-hydroxyapatite/chitosan composite for cadmium ions removal in wastewater treatment. J Taiwan Inst Chem Eng 45(4):1571-1577

204. Sheshmani S, Ashori A, Hasanzadeh S (2014) Removal of acid orange 7 from aqueous solution using magnetic graphene/chitosan: a promising nano-adsorbent. Int $\mathrm{J}$ Biol Macromol $68: 218-224$

205. Bhattacharyya R, Ray SK (2014) Micro-and nano-sized bentonite filled composite superabsorbents of chitosan and acrylic copolymer for removal of synthetic dyes from water. Appl Clay Sci 101:510-520

206. Xiao G, Su H, Tan T (2015) Synthesis of core-shell bioaffinity chitosan-TiO 2 composite and its environmental applications. J Hazard Mater 283:888-896

207. Sharma VK, Yngard RA, Lin Y (2009) Silver nanoparticles: green synthesis and their antimicrobial activities. Adv Coll Interface Sci 145(1-2):83-96

208. El-Shanshoury AE-RR, ElSilk SE, Ebeid ME (2011) Extracellular biosynthesis of silver nanoparticles using Escherichia coli ATCC 8739, Bacillus subtilis ATCC 6633, and Streptococcus thermophilus ESh1 and their antimicrobial activities. ISRN Nanotechnol 2011:7

209. Thakkar KN, Mhatre SS, Parikh RY (2010) Biological synthesis of metallic nanoparticles. Nanomedicine 6(2):257-262

210. Ingale AG (2013) Biogenic synthesis of nanoparticles and potential applications: an eco- friendly approach. J Nanomed Nanotechnol 04(02):1-7

211. Mohanpuria P, Rana N, Yadav S (2008) Biosynthesis of nanoparticles: technological concepts and future applications. J Nanopart Res 10(3):507-517

212. Shankar SS et al (2004) Rapid synthesis of $\mathrm{Au}, \mathrm{Ag}$, and bimetallic Au core-Ag shell nanoparticles using Neem ( $A z a-$ dirachta indica) leaf broth. J Colloid Interface Sci 275(2):496-502

213. Ghorbani HR et al (2011) Biological and non-biological methods for silver nanoparticles synthesis. Chem Biochem Eng Q 25(3):317-326

214. Li X et al (2011) Biosynthesis of nanoparticles by microorganisms and their applications. J Nanomaterials 2011:16

215. Das RK et al (2015) Biological synthesis of metallic nanoparticles: making sense of greenness versus unforeseen arbitraries. J Hazard Toxic Radioact Waste 20:04015015

216. Gautam A, van Veggel FCJM (2013) Synthesis of nanoparticles, their biocompatibility, and toxicity behavior for biomedical applications. J Mater Chem B 1(39):5186-5200

217. Buzea C, Pacheco I, Robbie K (2007) Nanomaterials and nanoparticles: sources and toxicity. Biointerphases 2(4):MR17MR71

218. Tyagi K (2013) Estimation of toxic effects of chemically and biologically synthesized silver nanoparticles on human gut microflora containing Bacillus subtilis. J Toxicol Environ Health Sci 5(9):172-177

219. Goodman CM et al (2004) Toxicity of gold nanoparticles functionalized with cationic and anionic side chains. Bioconjugate Chem 15(4):897-900

220. Connor EE et al (2005) Gold nanoparticles are taken up by human cells but do not cause acute cytotoxicity. Small 1(3):325-327

221. Derfus AM, Chan WCW, Bhatia SN (2004) Probing the cytotoxicity of semiconductor quantum dots. Nano Lett 4(1):11-18

222. Schubert D et al (2006) Cerium and yttrium oxide nanoparticles are neuroprotective. Biochem Biophys Res Commun 342(1):86-91

223. Bosi S et al (2003) Fullerene derivatives: an attractive tool for biological applications. Eur J Med Chem 38(11-12):913-923 